Atlantic, for which purpose it obtains observations of wind, weather, barometer, and temperature of air and sea from observers in the Mercantile Marine who are willing to assist in the advancement of our knowledge of the weather in this way, and a daily chart is prepared giving a picture of the weather over the Atlantic and for the adjacent continents of Europe and America for 8 o'clock each morning. A study of these is helpful to the furtherance of our better understanding of meteorology and its complicated problems, but necessarily these charts picture only what is past, although they afford an explanation of success or failure in forecasting, and often show why an unexpected and altogether unlooked for change of weather has occurred. These charts are prepared as closely as possible to date of occurrence. When the Meteorological Office has the advantage of receiving messages by the wireless telegraphy, both from outgoing and incoming Atlantic liners, they will unmistakably possess a power which has long been known to be wanting. The Daily Telegraph has taken the initiative, and it is to be hoped that the arrangements which the Meteorological Office has already been endeavouring to make with Lloyd's for fuller information will shortly meet with that success which it deserves, for the advancement of science and for the public benefit.

With the further development of Marconi's system there seems every reason to hope that we in England may be placed much on the same footing as Denmark, for example, is now, in full possession of the knowledge of what is going on for several hundred miles to the westward of the base of operations, to the immense gain of the forecaster for the country concerned. Knowing what is going on over the Atlantic to the westward of us would not only secure greater accuracy of forecast, but the time limit could probably be extended from twenty-four hours, as at present, to, say, forty-eight hours at least.

\section{PROF. J. D. EVERETT, F.R.S.}

THE death of Prof. Everett has removed a familiar figure from the ranks of English physicists. The news of his death came as a shock to his many friends and others acquainted with his great vitality and his intellectual activity, which seemed to remain quite unimpaired by advancing years. Some seven years ago he retired from teaching work in Queen's College, Belfast, where, for upwards of thirty years, he had occupied the chair of natural philosophy. Since that time he resided in London, where he took an active part in the proceedings of scientific societies, specially of the Physical Society, of which he was a vicepresident.

Dr. Everett's name has been familiar to many generations of students of physics through his admirable translation of Deschanel's treatise, which has long served as a standard text-book. Many editions of this were called for; and as each fresh edition was carefully brought up to date by additions and alterations, the book became ultimately almost entirely a new work. Another very important service to physical science was rendered by the publication of Prof. Everett's book on the C.G.S. system of units. This very useful compendium made its first appearance at the time when the question of fixing the practical electrical units was being discussed, and proved of material service in that connection. It gives not only clear and precise definitions of fundamental quantities, but also numerical data carefully selected and compiled.

Dr. Everett's earliest original work consisted of an experimental determination of the elastic constants of No. 1817 , voL. 70] certain solids. Subsequently he confined himself to work on his text-books and to theoretical investigations. His published papers, which appeared for the most part in the Philosophical Magazine or in the pages of this Journal, show by their subjects the wide range of his interests. Thus recent papers treat of the theory of combination tones, Hering's colourtheory, dynamical illustrations of optics, the theory of rent, the properties of certain linkages, and the mathematics of bees' cells. His last paper, elucidating a point in connection with Osborne Reynolds's theory of the universe, appeared only a month or so ago. $\mathrm{He}$ served for many years as recorder of the British Association Committee for Investigation of Lnderground Temperatures, and did much valuable work in drawing up the annual reports.

Dr. Everett's energy and ingenuity found outlets also in directions not purely scientific. He was the inventor of a system of shorthand which has found many adherents. He devised an extended form of slide-rule, ingeniously arranged on sheets of cardboard. An early and enthusiastic votary of cycling, he was much interested in cycle construction, and was an active member of the Cyclists' Touring Club. A man of great kindliness and geniality, he will be missed in many circles. His pupils will remember him always with gratitude and affection.

\section{THE BRITISH ASSOCIATION AT CAMBRIDGE.}

THE meeting of the British Association at Cambridge concluded yesterday. The meeting has been in every way a success. In all the sectional sessions large attendances were secured, and the general and social meetings were all successfully carried through and greatly appreciated. In regard to numbers of members, the Cambridge meeting was the largest since the Liverpool meeting of 1896 . At this meeting there were $318 \mathrm{I}$ members and associates, at the meeting just concluded at Cambridge the number of members and associates was 2783 . It is interesting to compare the numbers of other large meetings with the one just held. The largest number of members and associates that have attended a meeting was at Manchester in 1887 , when the number was 3838 . At Newcastle in 1863 there were 3335 , at Liverpool in 1870 there were 2878 , and at Bath in I864 the number was 2802 . These meetings are the only ones which have had a larger attendance than that at Cambridge, and it is interesting to observe that in all these cases the meeting has been in a large city where the number of resident members and associates naturally would be very much larger than in a comparatively small town such as Cambridge. Compared with recent years the numbers show a large increase. Last year in Southport 1754 attended the Association, in Belfast the year before there were 1620, and in Glasgow in I901 there were rgi2. Comparing the meeting just concluded with the three former meetings held in Cambridge we find a great increase in numbers. In 1833 there were 900 members and associates, in 1845 there were 1079, and in 1862 , $116 x$.

The cause of the great popularity of the Cambridge meeting this year is undoubtedly to be found in the great growth and expansion in scientific work at the University during the last twenty-five years. The work done at Cambridge in the last quarter of the nineteenth century in all branches of science has made Cambridge a great centre of attraction for scientific men the world over. At this year's meeting there were present I2I foreign members. Amongst these there was a large number of physicists attracted by 
the Cavendish Laboratory, and the interest attaching to it owing to the great succession of Profs. Maxwell, Rayleigh, and J. J. Thomson. The school of research built up by $\mathrm{J}$. J. Thomson has done so much in investigating, especially the new field opened in physics in the last few years, that "the Cavendish" has attracted physicists from all parts of the world. In other branches of science also, in chemistry, in physiology, in zoology, in engineering, in anthropology, in fact, in almost all departments, the new spirit of research, which has permeated Cambridge, and the men who have done so much to put Cambridge in the forefront of progress in scientific discovery, has made this University a great attraction to all those who have the advance of science at heart.

The large number of serious students attending all the sectional meetings this year has been an encouraging sign, showing that the increase in numbers has not been due merely to the camp followers of science, but to those who are really interested, and who wish to make of the British Association more than an annual week of excursions and garden parties. There have been, of course, a large number of members and associates who have not joined the Association for any other purpose than a week of pleasant social meeting, and in some ways it seems a pity that there should be such a number who do not really add to the usefulness of the meeting.

This is not the place for any detailed account of sectional meetings, full accounts of these will appear in other columns of NATURE. Here all that is necessary is to give a short account of the general meetings and lectures. With regard to the entertainment of the Association there has been expressed by visitors to Cambridge nothing but satisfaction. The reception of the members of the Association by the President in Trinity College was a most successful meeting. Over 2000 members attended and were received by $\mathrm{Mr}$. Balfour in the hall. The grounds and courts were illuminated. The President's address was delivered in the Corn Exchange, which was decorated for the occasion, and above 2000 members were present. At Peterhouse about 600 of the members were entertained by invitation of the Master and Fellows. The grounds of the college were illuminated, and a very pleasant evening was spent.

On Friday evening a reception was held at the invitation of the Cambridge Philosophical Society in the combination room and hall of St. John's College Dr. Baker, the President of the Society, presided. This reception, which was limited in number, and for gentlemen, especially the foreign members of the Association, was perhaps the most successful meeting held. Smoking was freely indulged in, and more was done in the way of promoting acquaintance and friendship between members of the Association than at any other time. Garden parties were held at Emmanuel College, by invitation of the High Sheriff, at Newnham and Girton Colleges, and at the Botanic Gardens, by the invitation of the Lord Lieutenant of Cambridgeshire and the Mayor of Cambridge. The lectures by Mr. J. W. Clark, Prof. Darwin, and Prof. Osborn were crowded, and Mr. Clark and Prof. Darwin repeated theirs to afford the many members who could not obtain tickets the opportunity of hearing them. On Monday honorary degrees were conferred in the Senate House upon representative leaders in science, and the speeches delivered on that occasion are printed elsewhere in this issue (p. 4i8).

Acting upon the suggestion of the council of the Association, several of the sections arranged discussions upon subjects of wide scientific importance, and devoted afternoon meetings to lectures of a semipopular character. The discussions have in each case elicited the expression of inspiring and authoritative opinion, and when the subjects of the afternoon lectures have been of a character which appealed to members of the Association in general, and not only to members of a section, the lectures have been attended by large and appreciative audiences. This year's experience shows unmistakably that when sufficient care is taken in the selection of suitajle lecturers and subjects, the afternoon addresses are most successful. For the benefit of members of the Association who are not actively engaged in scientific work, but are interested in the progress of natural knowledge, it is to be hoped that these lectures will be given a place in the programme of each section in future meetings.

In the physics sub-section of Section A, great interest was shown in the discussion opened by Prof. J. J. Thomson on radio-activity. Amongst other papers perhaps the most interesting was that of Prof. Rubens, on the optical properties of metals, in which he showed that the theory of Maxwell led to results for reflection from metallic surfaces, which agreed within the limits of experimental error with the actually observed results for infra red rays of wave length about thirty times that of visible light. This result was particularly interesting in the university of Maxwell, as for many years the nonagreement of the theoretical and observed results was regarded as limiting the applicability of Maxwell's theory to the range of steady currents and slow oscillations. The discussion on $n$-rays left those who heard it with the conviction that the phenomena said to be observed correspond to no objective physical reality. In the section devoted to economics the morning given to discussion of fiscal problems was of general interest. The opinion of scientific economists, as far as it was represented in the discussion, is distinctly in favour of free trade. The articles dealing with the separate sections will describe the results of the sectional meetings; the two mentioned have been introduced because of their general interest; the new theory of the constitution of matter being one which has appealed to all men of science as well as physicists, and the economic question being also one of interest wider than Section F. With regard to the new views of the constitution of matter, it seems unnecessary to take quite so serious a view as was expressed by the President of the Association. The new view is in no way contrary to older theories of the atomic and molecular theories of matter, but is an extension and explanation of these, and in the hands of Prof. J. J. Thomson, has made, at any rate to physicists, a simplification and rational view of these without introducing the question of physical reality.

One of the most interesting features of the meeting has been the museums and laboratories, which have been open for inspection during the Association week. Special mention should be made of the zoological exhibits, and the exhibit of teaching apparatus and experiments by Mr. Searle, in the Cavendish Laboratory. Among the demonstrations we may mention, as of special interest, that of Prof. R. W. Wood, of Baltimore, of the anomalous dispersion of sodium vapour; that of Messrs. Heycock and Neville, on methods of investigating metallic alloys, and of Prof. Schäfer, on methods of artificial respiration.

The report of the council which was presented to the general committee on August i7 referred to the organisation of the deputation which waited upon the Prime Minister on July ${ }_{5}$, to urge the importance №. I8I7, voL. 70] 
of increased national provision being made for university education. The result of the action thus taken by the president at the request of the council has already been described in Nature (July 21, p. 27r). Several matters relating to the business of the officers of sections were mentioned in the report, and it was recommended that the following resolution sent to the council by the general committee for consideration, should be acted upon :-

That the sectional committees be continued in existence until the new sectional committees are appointed, and be authorised to bring to the notice of the council in the interval between the annual meetings of the Association any matter on which the action of the council may be desired in the interests of the several sections, and that a committee may be summoned at any time by the president of the section, or by the council.

Hitherto, the organisation of the work of the sections, and the arrangement of the programme, have been in the hands of the officers, but by this resolution the sectional committees are given a voice in the matter during the year between one meeting and the next, instead of ceasing to exist at the close of the meeting at which the members are appointed. The sectional committees, as at present constituted, are, however, so large as to be almost unmanageable as working committees, and probably the simplest practical way to secure continuity would be to select, say half a dozen members, from each committee to work with the officers during the year. The only other plan would be to limit the number of members to be appointed upon the committee of each section.

The members of sectional committees are not, in virtue of their membership, expected to take any essential part in the work of a section, though they may, and occasionally do, attend the meetings of the committees upon which they are appointed. In some cases vice-presidents understand their functions to bc of the same negative significance, and neither attend the meeting for which they are appointed, nor send a timely notice of their inability to do so. To avoid this inconvenience the council has resolved that gentlemen nominated as vice-presidents of sections be informed that their attendance at the meeting for which they are nominated is expected.

Arrangements for the South African meeting in I905 have received much attention during the year from a committee of council appointed for the purpose. The first half of the meeting will be held at Cape Town and the second half at Johannesburg, and official visits of the Association will be made to Natal and the Orange River Colony, in each of which colonies one or more discourses will be delivered by prominent members of the Association. The meeting will open at Cape Town on August ${ }_{15}$, so that members starting for South Africa at the end of July will be able to spend at least three weeks in the colonies, and be back in England by the end of September. Prof. George Darwin will be the president of this meeting.

At the meeting of the general committee on August ig the invitation to meet at York in 1906 was accepted unanimously.

Upon the proposal of Sir J. Dewar, seconded by Sir A. Rücker, Prof. J. Perry was elected to fill the office of general treasurer, in succession to Dr. G. Carey Foster, who has resigned that post.

$A$ vote of thanks to Sir Norman Lockyer for the way in which he has discharged his presidential duties was proposed by Sir Henry Roscoe and seconded by Prof. Perry, and carried unanimously, as was also a similar vote of thanks to Dr. Carey Foster, moved by Sir A. Geikie and seconded by Major Macmahon.

No. I817, vOL. 70]
SECTION A.

SUBSECTION, COSMICAL PHYSICS.

Opening Address by Sir John Eliot, K.C.I.E., M.A., F.R.S., Chairman OF the SUbsection.

WhEN the suggestion was made to me that I should preside over this important Subsection my first thoughts prompted me to decline the honour. The position had been filled during the past two years by two distinguished physicists, both of whom had dealt chiefly with the problems and the position of meteorological science, and hence I thought that it should be offered to some representative of cosmical physics. I also doubted whether an official meteorologist whose time has been chiefly given up to duties of administration could have anything of interest to communicate to you. However, on fuller consideration it occurred to me that I might be able to place before you some features of Indian meteorology leading up to and assigning, as I hope, adequate reasons for the study of a portion of the field of tropical meteorology as a whole.

My address consists of three parts, viz.

(i) A brief sketch of the broad features of the meteorology of India in their relations to the general meteorology of the Indo-oceanic region.

(2) Statement of abnormal features of the meteorology of that area for the unique period $1892-1902$ illustrating the remarks in the preceding sketch.

(3) Suggestion of the co-ordination of the meteorological observations of the British Empire and the creation of a central office for the investigation of problems of general meteorology.

India is the most typical example of monsoon conditions, that is, of opposite air movements of six-monthly period which, in its case, depend on the annual temperature changes in the sea and land areas of the Indian Ocean and continent of Asia. The monsoon conditions in India are intensified by its unique position and topography. It projects southwards into the Indian seas over $15^{\circ}$ of latitude, and is protected northwards by the vast barrier of the Himalaya Mountain range and Tibetan plateau. The axis of the Himalayan range is at least 2000 miles in length and has an average elevation of more than 20,000 feet. The extent of country more than 10,000 feet in elevation to the north of India is from 300 to 500 miles in width. These figures will give some idea of the magnitude of India's northern barrier.

During one period of the year there is an outflow in the lower atmosphere from land to sea. The direction of the lower air drift in India is determined in part by the lie of the mountains and river valleys, and is from north-east over the greater part of the Indian seas. January is the month most typical of this air movement and of the accompanying weather conditions.

During another portion of the year the lower horizontal air movement is from sea to land. This movement is much steadier and more powerful and influential in every respect than the former. July and August are the months most representative of the totality of the weather conditions of this period.

Conditions similar to those of January prevail in their entirety from about the middle of December to the end of February or middle of $\mathrm{March}$-the period known in India as the cold weather or cool season. The lower horizontal air movement in India during the period has its origin in Upper India, where it is very feeble, and whence it increases seawards and is of moderate force in the Bay of Bengal (mean force 2 to 3 , Beaufort scale) and the Arabian Sea (mean, 2 to 4 ). It is fed to a certain extent by drift down the river valleys, and passes in the NorthWest India frontier hill ranges. There is, on the other hand, no general drift down the Himalayan river valleys or across the main ranges from Central Asia. The normal air movement in the Western Himalayas (and perhaps the whole range) is an alternating up and down, or day-andnight movement, depending upon the diurnal heating and cooling of the plains of Northern India. Hence India (in its lower air movement) is at this time completely shut off from Central Asia.

The lower air movement is continued over the Indian seas southwards to a region of vertical movement over a narrow belt a little to the south of the equator. This belt 
is also the goal of the lower air movement of the south-east trades circulation at this time. The equatorial belt of calms is hence the termination of the lower air movement of the south-east trades and north-east monsoon. It is chiefly an area of uptake, and of outflow northwards and southwards, to replace the lower air inflow from the distant south and north. The influx to the Indian land area occurs chiefly or entirely in the upper and (perhaps) middle atmosphere. There is also, as indicated by the wind directions in the lower Assam and Burma hills, an influx from the adjacent seas in the upper portion of the lower atmosphere. ${ }^{1}$ The diurnal land and sea breezes alternate with great regularity on the west coast south of Gujarat during this period, but probably do not contribute to the general upper influx compensating in part or whole the lower outflow.

The circulation over the Indo-oceanic region hence consists at this time of two semi-independent circulations, with a common sink or goal for the lower air movement, which shifts with the season and with the relative strengths of the two movements. It is hence probable that they react on each other to some extent, and possible that general abnormal actions may affect the two similarly.

The normal weather during the period is similar to that which obtains in anticyclonic periods during the summer in Central Europe-viz., the prevalence of light winds, with clear or lightly clouded skies, low humidity, moderate temperature, and large diurnal range of temperature, with a bracing, exhilarating atmosphere.

It is interesting to note that the air movement in India itself is from opposite directions in Northern India and the peninsula, with a belt of unsteady movement over the area of the Vindhya and Satpura hill ranges. The variations of weather conditions from the normal are as a rule inverse in these two regions-viz., Extra-tropical and Tropical India.

The season of the opposite air movement is present in its most complete form in July and August, and lasts from the beginning or middle of June to the middle or end of September. It commences as a lower air movement in an anticyclonic region over the South Indian Ocean, and is thence continued northwards to Abyssinia, South Arabia, India, and Burma. Persia, Afghanistan, and Baluchistan (where dry hot north-west winds chiefly prevail) are outside the field of this movement. The direction of the movement is from south, with more or less easting to the south of the equator, and with more or less westing to the north of the equator, dependent in part upon the earth's rotation and in part upon local conditions and the influence of neighbouring land areas, and hence more effective in the Bay of Bengal than in the Arabian Sea. This lower air current advances over an extensive tropical oceanic region before it reaches Southern Asia, and hence arrives charged with vast stores of aqueous vapour, which it discharges chiefly over the peninsulas of Southern Asia and the mountain region of Abyssinia.

The regions of rainfall indicate the areas of upward novement terminating the 'ower advance of the current. The circulation is undoubtedly maintained in large part by the release or addition of energy due to the condensation of its enormous stores of aqueous vapour. The lower air movement is of very considerable elevation, estimated at 15,000 to 20,000 feet in India. Above it is the outward upper return movement, in part only compensatory, and in part probably slowly filling up the Central and Southern Asian low-pressure region. The movement exhibits some interesting features in India, due to the fact that of the three areas to which it is mainly determined India alone is subject to a double influx from two sea areas in opposite directions. The current from the Arabian Sea passes eastwards across the Malabar, Konkan, and North Bombay coasts, the peninsula and Central India. The Bengal current is deffected in the north of the Bay and Bengal, and advances in a westerly direction up the Gangetic plain. Between the areas or fields of the two currents (roughly proportional to their relative strength and importanceviz., about 2 to $\mathrm{I}$ ) is a debatable area of variable winds and low pressure. This trough of low pressure varies in position with the relative strengths of the two currents. The

1 In India the lower atmosphere may be defined as from o to 5000 feet, the middle atmosphere from 5000 to 15,000 or 20,000 feet, and the upper atmosphere above 20,000 feet. cyclonic storms of the period, which are of comparatively frequent occurrence, advance along the trough. It is hence a factor of considerable importance in determining the distribution of the rainfall of the period. The trough is purely a resultant of the peculiar conditions of the air movement, and is not the cause of that movement; in other words, it is determined by it, and does not determine it.

The transformation of the double circulation of the northeast monsoon period into the single circulation of the southwest monsoon over the Indo-oceanic region next requires consideration. It is evident that the chief stages in this change are ( $\mathrm{r}$ ) the discontinuance of the vertical movement over the equatorial belt; (2) the extension of the trade winds of the south-east trades across the equatorial belt with an accompanying increase of pressure and of horizontal air movement; (3) the continuance of that northerly movement over the Indian seas into the peninsulas of Southern Asia.

The marine data of the Indian seas collected during the past fifteen years establish fully that this transformation is primarily due to actions in the Indian Ocean, producing a movement resembling in many respects that of a bore or storm wave. The actual transition may hence be described as catastrophic, due to impulsive action.

It is preceded in India by a period of preparation (as it may be termed), when pressure and other conditions are slowly established in Southern Asia, which directly contribute to the advance of the monsoon winds over the Indian seas, but which in no way assist the preliminary burst across the equator, the first stage towards the establishment of the south-west monsoon circulation.

This preliminary period is the hot-weather season, lasting from about the middle of March to the middle of June (on the average in Northern India). During this period temperature increases rapidly until the last week in May or first week of June, when maximum day temperatures ranging between $120^{\circ}$ and $125^{\circ}$ are usually recorded in the driest and hottest interior districts of Northern and Central India. Pressure decreases pari passu in the heated land areas of Southern Asia, which become areas of low pressure and indraught relative to the neighbouring seas. The indraught only extends to a comparatively short distance landwards and seawards from the coasts, more especially in the larger sea area, the Arabian Sea, over the centre of which light variable or northerly winds obtain even immediately before the advance of the monsoon currents. In the interior of Northern and in Central India exceedingly dry and hot westerly winds prevail with great steadiness.

The weather in India during this period depends almost entirely upon local thermal actions and contrasts of temperature and humidity conditions. Skies are generally free from cloud, but the air is more or less charged with dust and is excessively dry (humidities of $I$ to 5 being of occasional occurrence in North-Western India).

The characteristic features of the dry season are hence most strikingly exhibited immediately before the advent of the wet monsoon. There is no gradual change over the greater part of India from one to the other such as would occur if the furnace, or Central Asia hot area, theory were correct. Over small isolated portions of India, including Tenasserim, Arakan, Lower Burma, Assam, Bengal, and Malabar, thunderstorms giving more or less heavy downpours occur in increasing frequency during the period. The rainfall is considerable to large in amount in these areas, and is of much agricultural value in some districts-e.g., in Assam for the tea crop. In those areas the transition to the rainy season is much less abrupt and spasmodic, the chief differences being that the rainfall in the wet season is more general and frequent, larger in amount, and rarely accompanies thunderstorms.

The transformation from the hot weather to the rains is usually effected between June $I$ and I $_{5}$. It commences in the equatorial belt with a considerable increase of pressure and air movement accompanying a strong rush of southerly winds, the continuation of south-east trade winds, across the equator. If the burst be sufficiently strong the rush is continued northwards over the Indian seas as a wave of disturbance, squally weather, heavy rain, and much violent electric discharge or action, invading areas characterised previously by light and variable winds and fine weather. The disturbance usually increases with its 
northward advance, and frequently, when it reaches lat. $12^{\circ}$ to $16^{\circ}$ N., it concentrates into a cyclonic storm. Such a storm almost invariably marks the commencement of the monsoon in the Bay of Bengal, and in about two out of five years in the Arabian Sea. The advancing humid currents in the rear of these initial cyclonic storms or waves of disturbance march over the sea areas in a few days, and thence cross the coasts towards which they are determined by the low-pressure regions in the land areas of Southern Asia, where they produce an almost complete reversal or transformation of the weather conditions, the result of which is that moderately high temperature and small diurnal range of temperature, great humidity frequently approaching saturation, much cloud, and frequent rain obtain for the next three months over the greater part of India, until, in fact, the middle or end of September.

The reverse change-viz., the withdrawal of the humid south-west currents-then commences, and is a slow process, requiring usually from two to three months for its completion.

This is due to a gradual decrease of strength, and hence to a fairly continuous contraction of the field of the current and also of its elevation or thickness. The current first withdraws from North-Western India, being replaced by light, variable, or north-westerly land winds. These land winds increase in extension and volume with the continued contraction of the south-west monsoon current. The more important phases of the contraction and withdrawal of that circulation from India are of especial interest. The first phase, the retreat of the current from North-Western India accompanies a rise of pressure over the Persian area and North-Western India, with a shift of the trough of low pressure from W.N.W. to N. or N.E. and corresponding change of direction of the average tracks of the storms of the period. This is followed after a short period of rain in North-Eastern India and Burma by a rise of pressure in Assam, Upper Burma, and Bengal, and the withdrawal of the monsoon current from those areas. The current then recurves over the centre of the Bay, in the same manner as during the monsoon proper over the north of the Bay and Bengal, and is directed or determined to the west or Madras coast of the Bay, which hence receives frequent rain during a short period of about two months-the rainy season of the eastern and southern parts of the peninsula south of Orissa and Ganjam.

These rains were formerly described as accompanying the setting in of the north-east monsoon on the Madras coast. That, however, is a misnomer, as the true northeast monsoon winds are dry land winds, and the rain-giving winds of this period in Madras are those of the south-west monsoon in its retreat or contraction down the Bay. The period during which this rainfall occurs is hence now usually termed the retreating south-west monsoon.

The year in India may hence be divided into two monsoons of nearly equal length, viz. :

(a) The north-east or dry monsoon.

(b) The south-west or wet monsoon.

The first terms are based on the general direction of the air movement in the Indian seas during the periods, and the second on the most prominent feature of the weather in India itself. Of an average annual total rainfall of $4 \mathrm{r}$ inches (according to the most trustworthy calculation), at least 85 per cent. falls during the wet season, and only I5 per cent. during the dry season.

The dry monsoon in India is subdivided into-

(I) The cold-weather period.

(2) The hot-weather period or transitional period of preparation for the south-west monsoon.

The wet monsoon is divided into-

(I) The south-west monsoon proper, or the period of general rains.

(2) The period of the retreating south-west monsoon and gradual slow establishment of the dry monsoon.

Each of these periods practically covers three months.

One of the most noteworthy features of the meteorology of India not referred to in the previous statement is that the storms of each period-viz., the cold-weather period, the hot-weather period, and the wet monsoon-are characteristic and special to the period. They are all in NO. I8I7, VOL. 70] the broadest sense of the word cyclonic in character; but they originate under different conditions and exhibit very different features in each of those periods.

The disturbances of the cold weather are large shallow depressions which originate in the upper humid return current of the north-east monsoon circulation, chiefly in the Persian plateau region, and which drift eastward with a slight southing across Extra-tropical India. Storms do not occur south of the Deccan or peninsula-dividing ranges during this period. These storms are chiefly remarkable for the frequent development of stationary secondary depressions in the Punjab, usually of much greater intensity than the primaries; a feature of which, I believe, there is no paralle elsewhere. They are of great importance, as they give the main snow supply to the Western Himalayas and the light but general occasional rain required for the wheat and other cold-weather crops of Northern India.

The storms of the hot weather are local disturbances of very limited extent, usually in large areas of slight depression, and are occasionally of remarkable intensity and great violence. In the areas to which the local sea winds of the period extend (more especially Bengal and Assam) they occur chiefly as local thunderstorms with violent winds and brief heavy downpours of rain, but sometimes as tornadoes rivalling those of certain districts of the United States in intensity and destructiveness. In the dry interior they occur as dust-storms, usually without rain, and are most violent in the driest districts, including Sind, the Punjab, and Rajputana. Occasionally, when the convective movement is especially vigorous, they develop into hailstorms of great intensity. The rainfall accompanying these hot-weather storms is of little general agricultural value except in the tea districts of Assam and Bengal.

Finally, the wet monsoon is characterised by the frequent occurrence of cyclonic storms of every degree of intensity and of very varying extent. The great majority of them originate in sea areas of nearly uniform temperature as disturbances in a massive current highly charged with aqueous vapour and subject to large variations of intensity and extension. The more prominent features of these storms, more especially of the most violent, including the hurricane winds, excessive rainfall, and the phenomena of the central calm and the accompanying storm wave, are too well known to require description. The chief importance of these storms, of which an average of about ten (of different degrees of intensity) occur every year during this period, arises from the manner in which they modify the distribution of the rainfall, discharging it abundantly over the districts traversed by the storms at the expense of the districts outside of their field.

The most important and variable feature of the weather in India from the practical standpoint is rainfall. Its value depends upon its amount and occurrence in relation to the needs of the staple crops. The measurement of rainfall is carried out, on a uniform system, at upwards of 2500 raingauge stations. The average distribution of rainfall, month by month and for each season, has been determined from the data of about 2000 stations. It should, however, be recognised that the probability that the rainfall will conform exactly to this distribution in any year is nil. Average rainfall charts represent a distribution about which the actual varies from district to district more or less considerably, the local variation for prolonged periods being practically compensatory. Such mean or normal data and charts are undoubtedly of value, more especially for the determination of rainfall anomalies and their relations to pressure, temperature, and other anomalies. There is apparently a tendency to assign a greater value to these charts of mean rainfall distribution than they deserve. Charts showing the amount and time distribution of the rainfall best suited for the requirements of the staple crops would-for India at least-be more interesting and valuable. This is a work that I regret has, for various reasons, not yet been carried out by the Indian Meteorological Department.

In most regions in India a moderate variation (positive or negative) in the amount of the rainfall is of comparatively small importance, more especially if the precipitation occurs in amount and at intervals suited to the requirements of the crops. During the thirty-year period $1874-1903$ there were six years in which the distribution of rainfall affected 
to a serious extent the crop returns over large areas, and the rainfall was not compensatory. In four of these years the drought was so severe and widely spread as to occasion famine, with its attendant calamities, over large areas. Severe droughts and famines occur at very irregular intervals. A noteworthy feature is that they frequently follow in pairs separated by intervals of two to four years.

The previous statement of the meteorology of India has indicated the chief conditions which affect the crop returns seriously or disastrously over large areas in India. They may be summed up briefly as follows :-

(a) The dry monsoon. Absence or unusual feebleness of cold-weather storms.

(b) The wet monsoon. General feebleness of the monsoon current, due either to corresponding feebleness of the southeast trades, or to unusual diversion to East Africa; or local feebleness in a part of India, due to local conditions, or to abnormal diversion to other rainfall areas in South Asia. These conditions give rise in the areas affected to one or more of the following features:-

(I) Prolonged delay in the commencement of the rains.

(2) Scanty rainfali during the season, with prolonged periods of fine, clear, hot weather.

(3) Early termination of the rains.

These features are as a rule more marked in the drier aistricts of the interior than in the coast districts. The effect on crop production is greatest and most disastrous in the following areas:--

(r) Central Burma.

(2) The Deccan, including the Bombay and Madras Deccan districts, and Hyderabad.

(3) North-Western and Central India, more especially the South Punjab, East Rajputana, and the United Provinces.

The following important inferences are based upon the preceding presentation of facts and the experience of the past thirty years :-

(r) The lower air movement of the south-west monsoon is the northward extension of the lower movement of the south-east trades. The latter is a permanent feature of the Indo-oceanic region, and the former a periodic invasion of the Southern Asian seas and peninsulas initiated over equatorial regions and propagated northwards to the southern mountain barrier of the Central Asian plateau.

(2) The primary factors determining this impulse across the equator (the first stage of the establishment of the south-west monsoon) are to be sought in the permanent field of the south-east trades, and are not due to actions in the heated areas of Southern or Central Asia.

(3) The pressure conditions in the heated areas of Southern Asia and North-East Africa determine the direction, volume, and intensity of the advance over the Indian seas to what may be termed three competing areas for rainfall (viz., Abyssinia, India, and Burma). These conditions are hence important factors in the third stage of the advance of the south-west monsoon current.

(4) The movement when fully established by these actions over the Southern Asian seas and peninsulas is continuedfirst, by the momentum of the lower circulation; secondly, by the release of energy accompanying aqueous vapour condensation; and thirdly, by thermal actions in Southern Asia, due to direct solar activity. The termination of the lower horizontal current by vertical movement occurs irregularly over the areas of frequent heavy rain in Southern Asia and Abyssinia, and not over a heated area in Central Asia.

(5) The total volume of aqueous vapour brought up by this circulation not only varies in amount from month to month during the season, but also from year to year. The largest variations (seasonal and annual) depend chiefly, if not entirely, upon actions in the source of supply-viz., the Indian Ocean. If those actions determine an increased or diminished supply across the equator into the Indian seas, there is a corresponding variation in the total precipitation of the three competing areas. Amongst such causes and actions may be prolonged and untimely diversion of the south-east trades into East Africa, as in 1896 , or general weakness of the air movement over the Indian Ocean, probably accompanying a displacement and decreased intensity of the southern anticyclone, as in 1899 .

(6) The relative distribution of the iotal rainfall in the three areas of discharge of the aqueous vapour of the monsoon currents probably depends upon the relative intensities of the pressure conditions established during the hot weather, which are continued for a part or the whole of the monsoon by actions depending on the rainfall resulting from the initial pressure conditions-an example of the persistence of meteorological conditions and actions which is a prominent feature of Indian meteorology. The total rainfall of each of the three areas may differ considerably from the normal, but there may be partial or complete compensation on the whole. Thus it is the general (but not the invariable) rule that the rainfall variations in Burma and Assam are usually inverse to those of North-Western India and also of India as a whole.

(7) The distribution of the rainfall in any one of the three competing areas (but more especially in India as the largest) may vary widely from the normal-considerable deficiency in some areas accompanying considerable excess in others. This in India is undoubtedly due to local conditions-e.g., local excess or deficiency of pressure at the commencement of the period and established during the previous hot weather. These pressure variations usually accompany abnormally prolonged and heavy snowfall or very scanty snowfall in the Western Himalayas.

(8) Local or general drought in India during the southwest monsoon may hence be due to-

(a) General weakness of the south-east trades circulation.

(b) Diversion of an unusually large proportion of the south-east trades to South-East or East Africa during the monsoon period.

(c) Larger diversion than usual of the monsoon currents to Burma or Abyssinia.

(d) Very unequal distribution in India itself, due to local conditions established during the antecedent hot weather.

These factors are given in the probable order of their importance.

(9) Scanty rainfall or drought during the dry season or north-east monsoon in Northern India results from absence or unusual feebleness of the cold weather storms which are the sources of rainfall at that time.

(Io) The most prolonged and severe droughts in NorthWestern and Central India are due to the partial or complete failure of the rainfall of at least two seasons in succession.

(II) As the two circulations in the Indian oceanic region have a common goal in the dry season (more especially from December to March), it is probable that variations in the strength of one circulation (more especially the larger) will modify the field and strength of the other circulation. It appears that this relation would be shown most strongly between the southern circulation and the upper movement of the northern circulation. And, as cold-weather storms are disturbances in that upper movement, it is possible-if not probable - that the larger variations in the number and intensity of the cold-weather storms and the amount of the cold-weather precipitation may be related to conditions in the south-east trades regions.

(I2) There appears to be little or no relation between the position and intensity of the Central Asian anticyclone and the number of the cold-weather storms and rainfall of Northern India in any season.

The meteorology of the period $1892-1902$ is of especial interest for its confirmation of the above inferences, more especially the phenomena of the variations of rainfall in India and the causes or actions to which they are due. The year 1891 was noteworthy for a severe local famine in Rajputana and the adjacent districts to the north and east consequent on prolonged and excessive snowfall in the Western Himalayas during the winter of $1890-91$. The following gives a brief summary of the more prominent features of the meteorology of this unique period :-

(I) The eleven-year period 1892-1902 corresponds in length to the sun-spot period, and it may be divided into two periods of unequal length-a short period of excessive rain and a long period of deficient precipitation. The maximum of the first period was in 1893 . The second period had three strongly marked minima in 1896, 1899, and 1901, that of 1899 being the absolute minimum. The following table gives, for convenience of reference, data of the mean annual and seasonal variations of rainfall of the Indian land area for each year of the period :-

$$
\text { No. I8I7, voL. 70] }
$$


Variation of Mean Actual Rainfall of Period from Normal.

\begin{tabular}{|c|c|c|c|c|c|c|c|}
\hline & & & & $\begin{array}{c}\text { Cold } \\
\text { Weather: } \\
\text { January and } \\
\text { February }\end{array}$ & $\begin{array}{c}\text { Hot } \\
\text { Weather: } \\
\text { March to } \\
\text { May }\end{array}$ & $\begin{array}{l}\text { South-west } \\
\text { Monsoon. } \\
\text { Complete } \\
\text { Period : } \\
\text { June to } \\
\text { December }\end{array}$ & $\begin{array}{l}\text { Whole } \\
\text { year }\end{array}$ \\
\hline 1891 & $\ldots$ & $\ldots$ & $\ldots$ & +0.34 & +0.37 & $-4 \cdot 25$ & -354 \\
\hline 1892 & $\cdots$ & $\cdots$ & $\ldots$ & -0.39 & $-0.2 \mathrm{I}$ & +5.69 & +5.09 \\
\hline 1893 & $\ldots$ & . & $\ldots$ & +1.63 & +272 & +472 & +9.07 \\
\hline I 894 & $\ldots$ & $\ldots$ & $\ldots$ & +0.48 & -0.76 & +675 & +6.47 \\
\hline 1895 & $\ldots$ & $\ldots$ & .. & $-0.0 \mathrm{I}$ & -0.23 & $-\quad 195$ & -219 \\
\hline 1896 & $\ldots$ & $\ldots$ & . & -0.42 & -0.82 & $\begin{array}{l}-3.59 \\
\end{array}$ & -483 \\
\hline I 897 & $\ldots$ & $\ldots$ & $\ldots$ & -0.01 & -0.12 & - 0.02 & -0.15 \\
\hline I898 & $\ldots$ & $\ldots$ & $\ldots$ & +0.50 & - I OO & +0.93 & $\div 0.43$ \\
\hline 1899 & .. & $\ldots$ & $\ldots$ & 0.38 & +0.58 & $-\mathrm{II} \cdot 34$ & $-\mathrm{I} 1 \cdot \mathrm{I} 4$ \\
\hline 1900 & $\ldots$ & $\ldots$ & $\ldots$ & -0.02 & -0.25 & -0.26 & -0.57 \\
\hline I90I & $\ldots$ & $\ldots$ & .. & $+\mathrm{I} \cdot 47$ & -0.48 & $-5 \times 12$ & -413 \\
\hline 1902 & $\ldots$ & $\cdots$ & $\ldots$ & -0.57 & +0.16 & $-\quad I \cdot 64$ & -205 \\
\hline & …- & - & & $\ldots \ldots$ & $+\ldots-\ldots$ & 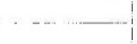 & $\ldots+\ldots-\cdots$ \\
\hline Norm & al $\mathrm{r}$ & ighl & & I inch & 5 inches & 35 inches & $4 \mathrm{I}$ inches \\
\hline
\end{tabular}

(2) The following gives the chief features of the rainfall of the first period, $1892-4$ :-

(a) The excess was almost as marked in the dry as in the wet season. This is strongly shown in the year 1893 of maximum excess.

(b) The excess was on the whole more strongly exhibited in the field of the Bombay than of the Bengal current.

(c) The rainfall of the dry season was as markedly in excess in Persia, Baluchistan, Afghanistan, and the Himalayan area as in Northern India.

(d) The maximum height of the Nile floods (in September) was above the average. They were abnormally high in 1892 and 1894.

(e) The rains were favourable over Australia and South Africa during this period, according to the reports received in India.

$(f)$ Hence, as a general inference, the rainfall was in general excess in each year of the period over the Indooceanic region, and not only in the south-west but also in the north-east monsoon in Southern Asia.

(3) The chief features of the rainfall of the second period, 1895-1902, in the Indo-oceanic region were as follows:-

(a) The rainfall was as deficient relatively to the normal in the cold weather as in the rains or wet season.

(b) The cold-weather or winter precipitation was almost continuously in marked defect in Asiatic Turkey, Persia, Afghanistan, Baluchistan, the Himalayan area, and South Tibet. The opposite variation obtained in Central Asia, as is shown by available data for Tashkend, Samarcand, Irkutsk, and other stations.

(c) The storms of the cold weather were fewer in number and feebler in character in each year of the period than on the average of the preceding sixteen years i $876-9$ r.

(d) The south-west monsoon rainfall was most largely in defect in the interior districts served by the Bombay current.

(e) There was a marked tendency in each year for late commencement and early withdrawal of the monsoon currents, and for deficient rainfall throughout the whole season over the greater part of India. These features were very pronounced in the years 1896,1899 . and I90I.

(f) The most remarkable feature of the period was that the region to the south of the equator, including South and East Africa, Mauritius, and Australia, was similarly affected.

In India the years 1896 and 1899 were years of severe drought, followed by famine over very large areas. The area in which the crops failed more or less completely was about 250,000 square miles in extent in 1806 and 500,000 square miles in 1899 . In the $1899-1900$ famine upwards of $6,500,000$ people were on famine relief for several months. The loss of cattle due to failure of water and fodder was very great, numbering many millions. In some districts from 90 to 95 per cent. of the cattle died off from slow NO. 1817 , VOL. 70$]$ starvation and want of water. In New South Wales and Queensland almost continuous drought prevailed from 1896 to 1902. It is estimated that more than fifty millions of sheep, value $12,500,000 l$, were lost in New South Wales. during these seven years of drought.

Mr. Hutchins, Conservator of Forests, Cape Town, states that drought prevailed more or less persistently over the Karoo region in South Africa from 1896 to 1903 , and that cattle and sheep perished by millions. He also states that the drought extended to British Central Africa from 1898 to 1903 .

The previous statements evidence the continuity, extension, and intensity of the drought.

The Nile floods followed very closely the variations of the rainfall in Western India. The floods of the years 1899 and roor were both amongst the lowest on record. This shows that the rainfall in the Abyssinian region was more or less generally in defect during the period and most largely in the years 1809 and 1901 , when the rainfall of the Bombay current was very deficient.

Hence, as a general inference, the period $x 895^{-1902}$ was characterised by more or less persistent deficiency of rainfall over practically the whole Indo-oceanic area (including Abyssinia). The economic results in the dry interior districts of India, South Africa, and Australia were the same-large loss of cattle and great loss of capital. The drought in Southern Asia was as marked in the north-east as in the south-west monsoon, and hence the variation was not seasonal but general.

The variations of temperature, humidity, and cloud in India during the whole period were large and in direct accordance with the rainfall. In other words, during the period 1892-94 the air was damper with lower temperature than usual, and cloud above the normal. On the other hand, from 1895 to 1902 temperature was steadily in excess, cloud less than usual, and humidity below the normal.

The most remarkable variation was that of the solar radiation as indicated by observations of the solar radiation thermometer (black bulb in vacuo).

The most interesting feature of the meteorology of the period $1892-1902$ is that the variations of the solar insolation are the inverse of those which might have been expected from the cloud and humidity data. In other words, solar radiation was in excess in the period of increased humidity and cloud, and in defect during the greater part of the period of drought, decreased humidity, and cloud. The series of eight curves exhibited, out of a larger number prepared from the data of a number of stations in India at which these observations are carefully recorded, show the most important facts, and indicate that there was a continuous decrease of insolation on the average of all stations from 1891 to 1902 . The curves for Aden, Calcutta, and Leh, it will be seen, agree in their most important features. The observations are quite concordant and probably represent a most important feature of the period. They indicate either a continuous and considerable decrease of emission of solar energy during the period, or unusually large absorption in the upper atmosphere. In order to decide this question comparison is necessary with similar data for other large areas as, for example, Europe and North America. It is, however, clear that in India the insolation data of this unique period are of exceptional interest and value.

The preceding statements have shown that variations of rainfall for prolonged periods similar in character have occurred, and may hence occur again, over the very large area including the Southern Asian peninsulas, East and South Africa, Australia, and, perhaps, the Indian Ocean. The abnormal actions or conditions giving rise to these large and prolonged variations must hence be persistent for long periods, and be effective over the whole of that extensive area, and hence cannot be inferred. with certainty from the examination of the data of one small portion of the area affected-e.g., India. The variations undoubtedly accompany variations in the complete atmospheric circulation over the Indo-oceanic area, and the effective forces or actions must be such as to influence the whole movement in a similar manner in the two monsoons or seasons of inverse conditions in Southern Asia. This inference furnishes a very strong reason for the conclusion that the meteorology of the whole area similarly affected from 1892 to 1902 should be studied as a whole, and not in fragmentary 
detail by various weather bureaus, and as at present without any co-ordination of the results of these bureaus.

The discussion has also indicated that the south-west monsoon current is a periodic or intermittent extension of the permanent circulation of the south-east trades to the peninsulas of Southern Asia, and also that variations in the strength, volume, and direction of movement of the latter affect the extension, volume, aqueous vapour contents, and precipitation of the south-west monsoon currents in Burma, India, and Abyssinia. This fact further emphasises the necessity for the co-ordination and systematisation of the work of observation in the Indo-oceanic meteorological province and the continuous and systematic examination and discussion of observations for the whole of that area.

It is, of course, possible that it may be necessary to extend this work to a larger area than the Indo-oceanic region. For Sir Norman Lockyer and Dr. Lockyer have shown that similar pressure variations to those of Bombay occur over a large portion of the Eastern Hemisphere, and variations of opposite sign (similar to those of Cordova) over a considerable part of the Western Hemisphere.

The Indian Meteorological Department, with the sanction of the Government of India, is now arranging to collect and tabulate data for the whole area between the Central Asian winter anticyclone and the permanent South Indian Ocean anticycione, and to utilise the information for the investigation of the causes of the large and general variations of rainfall in Burma and India from year to year. This extension of its labour is recognised as necessary for the improvement of the seasonal forecasts, an important feature of the work of the Department the value and importance of which are fully recognised by the Government of India.

Possibly the practice of the Indian Meteorological Department in the preparation and issue of long-period or seasonal forecasts is considered to be not only unscientific, but not justified by comparison with facts. Prof. Cleveland Abbe, in his paper on "The Physical Basis of Long-range Weather Forecasts," expresses his opinion that "we are warranted in saying that during the thirteen years (I888-1900) the only real failure has been that of the prediction of the monsoon season of $\mathrm{I} 899$, the year of phenomenally great drought in that country." This opinion is probably more favourable than I should myself give, but it is the opinion of an independent meteorologist eminently qualified to give a judgment in the matter.

My own opinion with respect to weather forecasts is that there appears to be too strong a desire for absolute accuracy, possibly due to public and newspaper criticism. Certainty is not possible in weather forecasts based on imperfect information, and in which the introduction of a single unknown factor in regions beyond observation-e.g., the upper or middle atmosphere-may completely alter the course of events. Percentages of success are an inadequate measure of the utility of forecasts. To be of real value as estimates of utility they should be calculated rather on the information required, and which might be reasonably expected, than on that actually given.

It appears to me that the striving after perfection in short-period forecasts to the exclusion of other claims is impeding the extension and progress of meteorology in other useful directions. It is absolutely essential that officials preparing or utilising forecasts should recognise that every forecast is based on imperfect information and experience, and hence that all important forecasts should be expressed as probabilities, and, whenever desirable, an estimate of the value of each probability be given.

The Government of India desires to have these seasonal forecasts, and has ordered its Meteorological Department to furnish them. The Government encourages the work, provides the additional means required by the Department for its proper performance, and issues the forecasts only to those who will use them as probabilities for practical guidance.

The importance of the work of seasonal forecasting in India may be judged from the following remarks:-

India is almost exclusively an agricultural country, with a population of nearly 300 millions. The material prosperity of practically the whole people is determined by the amount and distribution of the periodic rains. The variations in the amount and period of the rains are occasionally so great as to produce the most disastrous results in the staple crops over large areas. In 1899, for example, the crops failed more or less completely over an area several times the extent of England.

There is probably no country where the meteorological problems, of which these rainfall variations form one feature, are of greater interest or more practical importance. The daily weather and rainfall reports are studied during the greater part of the year with the closest attention by the officials, from the Viceroy downwards.

The Government is hence keenly interested in meteorological observation and investigation, and is most anxious to improve its meteorological service and utilise it for fractical purposes, of which seasonal forecasting is one of the most important. To give two examples. A reassuring forecast at a critical period, followed by its realisation, might be of the greatest value to the agricultural population of a large province, as well as to the local and Imperial Governments. Again, a statement or forecast the probability of which was, say, at least to to $\mathrm{I}$ that the rains would fail more or less completely during a season over a large area might enable the Government to carry out early prudential measures for relief in the most economical and effective manner with the means at its disposal. The preparation and issue of seasonal forecasts will hence, I am confident, be in the future, as in the past, one of the most important duties of the Indian Meteorological Department.

There are several points in connection with weather fore casting in India which it is desirable should be borne in mind. The first is that weather in India is distinguished rather by the massiveness, intensity, and persistence of abnormal features than by the frequency and rapid succession of important weather changes. It is chiefly on this account that daily weather forecasts, even if they could be communicated with the necessary rapidity, are of no value to the Indian agricultural population. Also, the empirical knowledge of the significance of the important variations as factors determining or indicating future weather accumulates much more slowly than in Europe, and it is hence doubly important that in India the empirical knowledge derived from very limited experience should be, so far as possible, regulated and controlled by theory and scientific knowledge. It should also be remembered that there are large differences between the meteorology of tropical and temperate regions, and also between the relation of crops to weather in India and England. The instincts, habits, beliefs, education of the body of the people in England and India also differ very widely. Hence the possibilities of the practical applications of meteorological science in India cannot be judged from the European standard, and may from that standpoint be unique.

The possibilities of usefulness of the work of seasonal or long-period forecasting in India are almost unlimited. To be acceptable and useful to the agricultural population of areas liable to drought they should be fairly accurate with respect to the dates of commencement and termination of the periodic rains, their general character, and the probable occurrence of prolonged breaks likely to be injurious to the chief food crops. If the forecasts were found to be fairly trustworthy in these respects, it is quite certain that the agricultural population would value them and use them. Indications of a growing belief in the utility and value of this feature of the work of the Department by the people in different parts of India are not wanting.

The Government of India has sanctioned large changes in its Meteorological Department in order to enable it to carry out the extensions of work that recent experience has shown to be desirable. The Department is kept in touch with scientific opinion and judgment at home through the Observatories Committee of the Royal Society. The relations to other scientific departments in India are maintained by a special committee termed the Board of Scientific Advice. The scientific staff has been largely increased. The solar physics observatory at Kodaikanal and the magnetic observatory at Bombay have been placed under the Meteorological Department with a view to the complete co-ordination of the departments of scientific investigation for which they are maintained. Observational data for the whole Indo-oceanic area are now being collected and tabulated with a view to the early publication of daily and monthly weather reports and charts of that area. 
The objects of this last extension have already been indicated. It will afford the Indian meteorologists the data necessary for the investigation of the extension and intensity of the more important variations in the meteorology of the whole region, to correlate the abnormal features in the atmospheric circulation over the area, and more especially to ascertain the causes of the occasional failure of the monsoon rains in India. Finally, it will, it is hoped, enable the Department to collect the information and acquire the additional experience necessary in order to render the seasonal forecasts more trustworthy and satisfactory than they have been during the past six or seven years.

The area to be dealt with (viz., the Indo-oceanic area) is partially covered by a number of independent meteorological systems, including those of Egypt, East, Central and South Africa, Ceylon, Mauritius, the Straits Settlements, and Australia. Large areas, as, for example, Arabia, Persia, Afghanistan, Tibet, and the greater number of the islands of the Indian Ocean, are now almost completely unrepresented.

The departments controlling these systems work independently of each other, chiefly for local objects, and are in no way officially correlated or affiliated. Their methods of observation and of discussion and publication of meteorological data differ largely. It is hence difficult, if not almost impossible, to make satisfactory comparisons of the data, and trace out for the work of current meteorology the extension or field of similar variations, their relations to each other, and their probable influence on the future weather.

The work which should be carried out in order that the investigation of the meteorology of the Indo-oceanic area might be effective and as complete as possible includes the following :-

(I) The extension of the field of observation by the establishment of observatories in unrepresented areas, and the systematic collection of marine meteorological data for the oceanic area.

(2) The collection and tabulation of the data necessary to give an adequate view of the larger abnormal features of the meteorology of the whole area.

(3) The direction by some authoritative body of the registration, collection, and tabulation of observations by similar methods in order to furnish strictly comparable data for discussion.

(4) The preparation of summaries of data required as preliminary to the work of discussion, and for the information of the officers controlling the work of observation in the contributory areas. The earliest publication of the data should be regarded as essential for the use of officers issuing seasonal forecasts.

(5) The scientific discussion of all the larger abnormal features in any considerable part of the area and their correlation to corresponding or compensatory variations in the remainder of the area by a central office furnished with an adequate staff.

(6) Possibly, sufficient authority on the part of the central office to initiate special observations required for the elucidation of special features for which there are no arrangements in the general work of the various systems.

The Indian Meteorological Department is making preparations to carry out a portion of this work; and will undoubtedly do the best it can single-handed with its limited means. It cannot do the work fully and as it ought to be done. It can do nothing which requires authoritative control over the remaining meteorological systems in the Indo-oceanic field. It is collecting information from those who are willing to supply it, and will utilise it for its special purposes.

It is evident the work can only be carried out fully by the co-operation of the various systems subject to limited control by a central office with acknowledged imperial or general authority behind it. The most important part of the work from the standpoint of the science of meteorology is the comparison and discussion of the whole body of observations. The constitution, position, and authority of the central office is hence of the greatest importance. It is quite certain that none of the meteorological systems directly concerned can provide such a central office. If the work is to be carried out fully and systematically it can only be arranged for in England, and by the English NO. I 8 I 7 , VOL. 70]
Government assuming the general direction and control. At the present time a section of the English Meteorological Office is devoted to the study of oceanic meteorology for the information of mariners. Another section should be created for the study of imperial meteorology for the benefit of its dependencies and colonies. I have reason to believe that the Government of India would contribute its share towards the cost of this extension of work.

In the preceding remarks are given the chief reasons for an important extension of work now in progress in the Indian Meteorological Department, an extension which can only be carried out imperfectly by that Department, but which could be performed with most valuable scientific results by the co-ordination of the labours of the weather bureaus concerned, with a central institution or investigating office in England under Government control.

Perhaps I may be permitted, from my Indian experience, to add some general remarks bearing on the methods and progress of meteorological inquiry.

In India the collection and publication of accurate current data relating to rainfall and temperature is required for the information of Government in its various Departments. The collection and examination of pressure and wind data by a central office with a view to the issue of storm and flood warnings is equally necessary. This work may, perhaps, be described as pertaining to descriptive or economic meteórology.

Economic meteorology, so long as it deals only with actual facts of observation, is not a science. Forecasts belong to the same department or branch of meteorology. They may be based on scientific theory and be obtained by scientific methods or the utilisation of empirical knowledge. The latter method is probably sufficient for by far the greater part of short-period forecast work, but the final development of that work and the preparation of long-period forecasts require the application of exact scientific methods and knowledge. And it is, perhaps, not too much to say that the extension of the range or period of forecasts is a measure of the progress of meteorology as a science. India, by the simplicity and massiveness of its meteorological changes (and perhaps Australia and Africa), appears to be best suited for the earliest experiments in this work.

India is, however, poor, not only in material wealth and capital as compared with England, but also in the appliances and means of scientific investigation, and hence looks to England for assistance and guidance in scientific matters. Unfortunately, England lags behind, not only the United States and Germany, but even behind India, in the important field of scientific meteorological inquiry. It will suffice to give a single illustration of the anomalous and inferior position which England takes in such matters.

All meteorologists and scientific men generally are agreed that the exploration of the middle and upper atmosphere by any available means-e.g., kites, balloons, \&c.--is of the utmost importance at the present stage of meteorological inquiry. The United States, France, and Germany have taken up the work vigorously. The English Meteorological Office is unable, for want of funds, to share or take any part in the work. The force of scientific and public opinion is apparently powerless to move the English Government to grant an extra five hundred pounds annually for this work. The English Government, on the other hand, some time ago suggested that the Indian Meteorological Department should assist. The Government of India, recognising the importance of the work, has provided the funds and sanctioned the arrangements necessary in order that its Meteorological Department may march with the most progressive nations in this investigation.

India has no body of voluntary observers or independent scientific workers and investigators. Whatever is required to be done to extend practical and theoretical meteorology can only be effected by the Government Department to which that work is assigned, with the sanction and at the cost of the Government--which naturally considers chiefly its practical wants in relation to its limited resources. It is, from one point of view, a painful if not quite an unexpected experience to me, on my retirement, to find that the Government of India is, in its attitude towards meteorological inquiry, more advanced, more liberal and far-sighted than the English Government, and that England has not yet taken up seriously the work of scientific meteorological 
investigation. There are undoubtedly too many observations and too little serious discussion of observations. The time has arrived when investigation should go hand in hand with accurate observation, and should direct and suggest the work of observation, and also that the sciences directly related to meteorology should be considered concurrently with it. There are undoubtedly definite relations between certain classes of solar phenomena and phenomena of terrestrial magnetism. The probability of definite relations between solar and terrestrial meteorological phenomena is aiso generally admitted.

Data for the determination of these relations are being rapidly accumulated, and numerous problems connected therewith are waiting and ripe for investigation. They are too large and complex to be undertaken by present English methods, and can only be attacked by a body of trained investigators under arrangements securing the continuity of method and thought requisite for the prolonged systemati inquiry gradually leading up to their complete solution.

It would hence be desirable to enlarge the scope of the cntral institution I have suggested, so as to include in its field of labour the investigation of the relation between solar and terrestrial meteorology and magnetism, so far as they can be solved by the comparison of the observations of the British Empire.

The central institution would thus have large and definite fields of work and most interesting problems for investigation. It would hence contribute towards the formation of a body of scientific meteorological investigators adequate to the importance and wants of the empire, and be of the highest educational as well as scientific value.

My predecessor in this position, Dr. Shaw, the head of the English Meteorological Office, made some remarks in his Address last year which deserve repetition in connection with this idea. He said: "The British Empire stands to gain more by scientific knowledge, and to lose more by unscientific knowledge, of the matter than any other country. It should from its position be the most important agency for promoting the advance of meteorological science, in the first place because it possesses such admirable varying fields of observation, and in the second place because with due encouragement British intellect may achieve as fruitful results in this as in other fields of investigation."

The establishment of the central institution as suggested above would provide a remedy for the defects pointed out by Dr. Shaw. The reorganisation of the English Meteorological Office is, I believe, under consideration. Is it too much to hope that a strong expression of opinion on the part of the British Association, and the influence of the learned University at which its present meeting is held, would induce the English Government to spend an additional $5000 \mathrm{l}$ or $10,000 l$. annually for the promotion of meteorological investigation and the establishment of a central imperial institution in London in connection with its Meteorological Office?

\section{SECTION D.}

ZOOLOGY.

Opening Address by Willyam Bateson, M.A., F.R.S., PRESIDENT OF THE Section.

In choosing a subject for this address I have availed myself of the kindly usage which permits a sectional president to divert the attention of his hearers into those lines of inquiry which he himself is accustomed to pursue. Nevertheless, in taking the facts of breeding for my theme, I am sensible that this privilege is subjected to a certain strain.

Heredity-and variation too-are matters of which no naturalist likes to admit himself entirely careless. Everyone knows that, somewhere hidden among the phenomena denoted by these terms, there must be principles which, in ways untraced, are ordering the destinies of living things. Experiments in heredity have thus, as I am told, a universal fascination. All are willing to offer an outward deference to these studies. The limits of that homage, however, are soon reached, and, though all profess interest, few are impelled to make even the moderate mental effort needed to apprehend what has been already done. It is understood that heredity is an important mystery, and variation another mystery. 'The naturalist, the breeder, the horticulturist, the No. I 817 , vOL. 70$]$ sociologist, man of science and man of practice alike, has daily occasion to make and to act on assumptions as to heredity and variation, but many seem well content that such phenomena should remain for ever mysterious.

The position of these studies is unique. At once fashionable and neglected, nominally the central common ground of botany and zoology, of morphology and physiology, belonging specially to neither, this area is thinly tenanted. Now, since few have leisure for topics with which they cannot suppose themselves concerned, I am aware that, when $I$ ask you in your familiar habitations to listen to tales of a no man's land, I must forego many of those supports by which a speaker may maintain his hold on the intellectual sympathy of an audience.

Those whose pursuits have led them far from their companions cannot be exempt from that differentiation which is the fate of isolated groups. The stock of common knowledge and common ideas grows smaller until the difficulty of inter-communication becomes extreme. Not only has our point of view changed, but our materials are unfamiliar, our methods of inquiry new, and even the results attained accord little with the common expectations of the day. In the progress of sciences we are used to be led from the known to the unknown, from the half-perceived to the proven, the expectation of one year becoming the certainty of the next. It will aid appreciation of the change coming over evolutionary science if it be realised that the new knowledge of heredity and variation rather replaces than extends current ideas on those subjects.

Convention requires that a president should declare all well in his science; but I cannot think it a symptom indicative of much health in our body that the task of assimilating the new knowledge has proved so difficult. An eminent foreign professor lately told me that he believed there were not half a dozen in his country conversant with what may be called Mendelism, though he added hopefully, "I find these things interest my students more than my colleagues." A professed biologist cannot afford to ignore a new life-history, the Okapi, or the other last new version of the old story; but phenomena which put new interpretations on the whole, facts witnessed continually by all who are working in these fields, he may conveniently disregard as matters of opinion. Had a discovery comparable in magnitude with that of Mendel been announced in physics or in chemistry, it would at once have been repeated and extended in every great scientific school throughout the world. We could come to a British Association audience to discuss the details of our subject-the polymorphism of extracted types, the physiological meaning of segregation, its applicability to the case of sex, the nature of non-segregable characters, and like problems with which we are now dealing-sure of finding sound and helpful criticism; nor would it be necessary on each occasion to begin with a popular presentation of the rudiments. This state of things in a progressive science has arisen, as I think, from a loss of touch with the main line of inquiry. The successes of descriptive zoology are so palpable and so attractive, that, not unnaturally, these which are the means of progress have been mistaken for the end. But now that the survey of terrestrial types by existing methods is happily approaching completion, we may hope that our science will return to its proper task, the detection of the fundamental nature of living things. I say return, because, in spite of that perfecting of the instruments of research characteristic of our time, and an extension of the area of scrutiny, the last generation was nearer the main quest. No one can study the history of biology without perceiving that in some essential respects the spirit of the naturalists of fifty years ago was truer in aim, and that their methods of inquiry were more direct and more fertile-so far, at least, as the problem of evolution is concerned-than those which have replaced them.

If we study the researches begun by Kölreuter and continued with great vigour until the middle of the sixties, we cannot fail to see that had the experiments he and his successors undertook been continued on the same lines, we should by now have advanced far into the unknown. More than this: if a knowledge of what those men actually accomplished had not passed away from the memory of our generation, we should now be able to appeal to an informed public mind, having some practical acquaintance with the 
phenomena, and possessing sufficient experience of these matters to recognise absurdity in statement and deduction, ready to provide that healthy atmosphere of instructed criticism most friendly to the growth of truth.

Elsewhere I have noted the paradox that the appearance of the work of Darwin, which crowns the great period in the study of the phenomena of species, was the signal for a general halt. The "Origin of Species," the treatise which for the first time brought the problem of species fairly within the range of human intelligence, so influenced the course of scientific thought that the study of this particular phenomenon-specific difference-almost entirely ceased. That this was largely due to the simultaneous opening up of lines of research in many other directions may be granted; but in greater measure, I believe, it is to be ascribed to the substitution of a conception of species which, with all the elements of truth it contains, is yet barren and unnatural. It is not wonderful that those who held that specific difference must be a phenomenon of slowest accumulation, proceeding by steps needing generations for their perception, should turn their attention to subjects deemed more amenable to human enterprise.

The indiscriminate confounding of all divergences from type into one heterogeneous heap under the name "Variation " effectually concealed those features of order which the phenomena severally present, creating an enduring obstacle to the progress of evolutionary science. Specific normality and distinctness being regarded as an accidental product of exigency, it was thought safe to treat departures from such normality as comparable differences: all were "variations" alike. Let us illustrate the consequences. Princess of Wales is a large modern violet, single, with stalks a foot long or more. Marie Louise is another, with large double flowers, pale colour, short stalks, peculiar scent, leaf, \&c. We call these "varieties," and we speak of the various fixed differences between these two, and between them and wild odorata, as due to variation; and, again, the transient differences between the same odorata in poor, dry soil, or in a rich hedge-bank, we call variation, using but the one term for differences, quantitative or qualitative, permanent or transitory, in size, number of parts, chemistry, and the rest. We might as well use one term to denote the differences between a bar of silver, a stick of lunar caustic, a shilling, or a teaspoon. No wonder that the ignorant tell us they can find no order in variation.

This prodigious confusion, which has spread obscurity over every part of these inquiries, is traceable to the original misconception of the nature of specific difference, as a thing imposed and not inherent. From this, at least, the earlier experimenters were free; and the undertakings of Gärtner and his contemporaries were informed by the true conception that the properties and behaviour of species were themselves specific. Free from the later fancy that but for selection the forms of animals and plants would be continuous and indeterminate, they recognised the definiteness of species and variety, and boldly set themselves to work out case by case the manifestations and consequences of that definiteness.

Over this work of minute and largely experimental analysis, rapidly growing, the new doctrine that organisms are mere conglomerates of adaptative devices descended like a numbing spell. By an easy confusion of thought, faith in the physiological definiteness of species and variety passed under the common ban which had at last exorcised the demon Immutability. Henceforth no naturalist must hold communion with either, on pain of condemnation as an apostate, a danger to the dynasty of Selection. From this oppression we in England, at least, are scarcely beginning to emerge. Bentham's "Flora," teaching very positively that the primrose, the cowslip, and the oxlip are impermanent varieties of one species, is in the hand of every beginner, while the British Museum Reading Room finds it unnecessary to procure Gärtner's " Bastarderzeugung."

And so this mass of specific learning has passed out of account. The evidence of the collector, the horticulturist, the breeder, the fancier, has been treated with neglect, and sometimes, I fear, with contempt. That wide field whence Darwin drew his wonderful store of facts has been some forty years untouched. Speak to professional zoologists of any breeder's matter, and how many will not intimate to you politely that fanciers are unscientific persons, and their concerns beneath notice? For the concrete in evolution we are offered the abstract. Our philosophers debate with great fluency whether between imaginary races sterility could grow up by an imaginary Selection; whether Selection working upon hypothetical materials could produce sexual differentiation; how under a system of Natural Selection bodily symmetry may have been impressed on formless protoplasm-that monstrous figment of the mind, fit startingpoint for such discussions. But by a physiological irony enthusiasm for these topics is sometimes fully correlated with indifference even to the classical illustrations; and for many whose minds are attracted by the abstract problem of inter-racial sterility there are few who can name for certain ten cases in which it has been already observed.

And yet in the natural world, in the collecting-box, the seed-bed, the poultry-yard, the places where variation, heredity, selection may be seen in operation and their properties tested, answers to these questions meet us at every turn-fragmentary answers, it is true, but each direct to the point. For if anyone will stoop to examine Nature in those humble places, will do a few days' weeding, prick out some rows of cabbages, feed up a few score of any variable larva, he will not wait long before he learns the truth about variation. If he go further and breed two or three generations of almost any controllable form, he will obtain immediately facts as to the course of heredity which obviate the need for much laborious imagining. If strictly trained, with faith in the omnipotence of selection, he will not proceed far before he encounters disquieting facts. Upon whatever character the attention be fixed, whether size, number, form of the whole or of the parts, proportion, distribution of differentiation, sexual characters, fertility, precocity or lateness, colour, susceptibility to cold or to disease in short, all the kinds of characters which we think of as best exemplifying specific difference-we are certain to find illustrations of the occurrence of departures from normality, presenting exactly the same definiteness elsewhere characteristic of normality itself. Again and again the circumstances of their occurrence render it impossible to suppose that these striking differences are the product of continued selection, or, indeed, that thev represent the results of a gradual transformation of any kind. Whenever by any collocation of favouring circumstances such definite novelties possess a superior viability, supplanting their " normal" relatives, it is obvious that new types will be created.

The earliest statement of this simple inference is, I believe, that of Marchant, ${ }^{1}$ who in 1719 , commenting on certain plants of Mercurialis with laciniated and hair-like leaves, which for a time established themselves in his garden, suggested that species may arise in like manner. Though the same conclusion has appeared inevitable to many, including authorities of very diverse experience, such as Huxley, Virchow, F. Galton, it has been strenuously resisted by the bulk of scientific opinion, especially in England. Lately, however, the belief in Mutation, as De Vries has taught us to call it, has made notable progress, ${ }^{2}$ owing to the publication of his splendid collection of observations and experiments, which must surely carry conviction of the reality and abundance of Mutation to the minds of all whose judgments can be affected by evidence.

That the dread test of Natural Selection must be passed by every aspirant to existence, however brief, is a truism which needs no special proof. Those who find satisfaction in demonstrations of the obvious mav amply indulge themselves by starting various sorts of some annual, say French poppy, in a garden, letting them run to seed, and noticing in a few years how many of the finer sorts are represented; or by sowing an equal number of seeds taken from several varieties of carnation, lettuce, or auricula, and seeing in what proportions the fine kinds survive in competition with the common.

Selection is a true phenomenon; but its function is to select, not to create. Many a white-edged poppy may have germinated and perished before Mr. Wilks saved the

1 Marchant, Mém. Ac. roy. des Sci. for 1719; 1721, p 59, Pls. 6-7. I owe this reference to Coutagne, "L'hérédité chez les vers à soie" (Bull. sci. Fr. Belg. Igor).

2 This progress threatens to be rapid indeed. Since these lines were written Prof. Huhrecht, in an admirable exposition (Pof. Sci. Mon'hly, July, I934) of De Vries' "Mutations-theorie," has even blamed me for having ten years ago attached any importance to continuous variation. Nevertheless, when the unit of segregation is small, something mistakably like continuous evolution must surely exist. (Cp. Johannsen, "Ueb. Erblich. keit in Populationen und in reinen Linien," rço3)

No. I8I7, voL. 70] 
individual which in a few generations gave rise to the Shirleys. Many a black Amphidasys betularia may have emerged before, some sixty years ago, in the urban conditions of Manchester the black var. doubledayaria found its chance, soon practically superseding the type in its place of origin, extending itself over England, and reappearing even in Belgium and Germany.

Darwin gave us sound teaching when he compared man's selective operations with those of Nature. Yet how many who are ready to expound Nature's methods have been at the pains to see how man really proceeds? To the domesticated form our fashions are what environmental exigency is to the wild. For years the conventional Chinese primrose threw sporadic plants of the loose-growing stellata variety, promptly extirpated because repugnant to mid-Victorian primness. But when taste, as we say, revived, the graceful Star Primula was saved by Messrs. Sutton, and a stock raised which is now of the highest fashion. I dare assert that few botanists meeting $P$. stellata in Nature would hesitate to declare it a good species. This and the Shirleys precisely illustrate the procedure of the raiser of novelties. His operations start from a definite beginning. As in the case of $P$. stellata, he may notice a mutational form thrown off perfect from the start, or, as in the Shirleys, what catches his attention may be the first indication of that flaw which if allowed to extend will split the type into a host of new varieties each with its own peculiarities and physiological constitution.

Let anyone who doubts this try what he can do by selection without such a definite beginning. Let him try from a pure strain of black and white rats to raise a white one by breeding from the whitest, or a black one by choosing the blackest. Let him try to raise a dwarf ("Cupid") sweet pea from a tall race by choosing the shortest, or a crested fowl by choosing the birds with most feather on their heads. To formulate such suggestions is to expose their foolishness.

The creature is beheld to be very good after, not before its creation. Our domesticated races are sometimes represented as so many incarnations of the breeder's prophetic fancy. But except in recombinations of pre-existing characters-now a comprehensible process-and in such intensifications and such finishing touches as involve variations which analogy makes probable, the part played by prophecy is small. Variation leads; the breeder follows. The breeder's method is to notice a desirable novelty, and to work up a stock of it, picking up other novelties in his course-for these genetic disturbances often spread-and we may rest assured the method of Nature is not very different.

The popular belief that evolution, whether natural or artificial, is effected by mass-selection of impalpable differences arises from many errors which are all phases of one -imperfect analysis---though the source of the error differs with the circumstances of its exponent. When the scientific advocate professes that he has statistical proofs of the continuity of variation, he is usually availing himself of that comprehensive use of the term Variation to which I have referred. Statistical indications of such continuity are commonly derived from the study, not of nascent varieties, but of the fluctuations to which all normal populations are subject. Truly varying material needs care in its collection, and if found is often sporadic or in some other way unsuitable for statistical treatment. Sometimes it happens that the two phenomena are studied together in inextricable entanglement, and the resulting impression is a blur.

But when a practical man, describing his own experience, declares that the creation of his new breed has been a very long affair, the man of science, feeling that he has found a favourable witness, puts forward this testimony as conclusive. But on cross-examination it appears that the immense period deposed to seldom goes back beyond the time of the witness's grandfather, covering, say, seventy years; more often ten, or eight, or even five years will be found to have accomplished most of the business. Next, in this period-which, if we take it at seventy years, is a mere point of time compared with the epochs of which the selectionist discourses-a momentous transformation has often been effected, not in one character but manv. Good characters have been added, it may be, of form, fertility, precocity, colour, and other physiological attributes, undesirable qualities have been eliminated, and all sorts of defects " rogued" out. On analysis these operations can be proved to depend on a dozen discontinuities. Be it, more. over remembered that within this period, besides producing his mutational character and combining it with other characters (or it may be groups of characters), the breeder has been working up a stock, reproducing in quantity that quality which first caught his attention, thus converting, if you will, a phenomenon of individuals into a phenomenon of a mass, to the future mystification of the careless.

Operating among such phenomena the gross statistical method is a misleading instrume it ; and, applied to these intricate discriminations, the imposing Correlation Table into which the biometrical Procrustes fits his arrays of unanalysed data is still no substitute for the common sieve of a trained judgment. For nothing but minute analysis of the facts by an observer thoroughly conversant with the particular plant or animal, its habits and properties, checked by the test of crucial experiment, can disentangle the truth.

To prove the reality of Selection as a factor in evolution is, as I have said, a work of supererogation. With more profit may experiments be employed in defining the limits of what Selection can accomplish. For whenever we can advance no further by Selection, we strike that hard outline fixed by the natural properties of organisms. We come upon these limits in various unexpected places, and to the naturalist ignorant of breeding nothing can be more surprising or instructive.

Whatever be the mode of origin of new types, no theoretical evolutionist doubts that Selection will enable him to fix his character when obtained. Let him put his faith into practice. Let him set about breeding canaries to win in the class for Clear Yellow Norwich at the Crystal Palace Show. Being a selectionist, his plan will be to pick up winning yellow cocks and hens at shows and breed them together. The results will be disappointing. Not getting what he wants, he may buy still better clear yellows and work them in, and so on until his funds are exhausted, but he will pretty certainly breed no winner, be he never so skilful. For no selection of winning yellows will make them into a breed. They must be formed afresh by various combinations of colours appropriately crossed and worked up. Though breeders differ as to the system of combinations to be followed, all would agree that selection of birds representing the winning type was a sure way to fail. The same is true for nearly all canary colours except in Lizards, and, I believe, for some pigeon and poultry colours also.

Let this scientific fancier now go to the Palace Poultry Show and buy the winning Brown Leghorn cock and hen, breed from them, and send up the result of such a mating year after year. His chance of a winner is not quite, but almost, nil. For in its wisdom the fancy has chosen one tvpe for the cock and another for the hen. They belong to distinct strains. The hen corresponding to the winning cock is too bright, and the cock corresponding to the winning hen is too dull for the judge's taste. The same is the case in nearly every breed where the sex-colours differ markedly. Rarely winners of both sexes have come in one strain-a phenomenon I cannot now discuss-but the contrary is the rule. Does anyone suppose that this system of "double mating "would be followed, with all the cost and trouble it involves, if Selection could compress the two strains into one? Yet current theory makes demands on Selection to which this is nothing.

The tyro has confidence in the power of Selection to fix type, but he never stops to consider what fixation precisely means. Yet a simple experiment will tell him. He may go to a great show and claim the best pair of Andalusian fowls for any number of guineas. When he breeds from them he finds, to his disgust, that only about half their chickens, or slightly more, come blue at all, the rest being blacks or splashed whites. Indignantly, perhaps, he will complain to the vendor that he has been supplied with no selected breed, but worthless mongrels. In reply he may learn that beyond a doubt his birds come from blues only in the direct line for an indefinite number of generations, and that to throw blacks and splashed whites is the inalienable property of blue Andalusians. But now let him breed from his " wasters," and he will find that the extracted blacks are pure and give blacks only, that the splashed whites similarly give only whites or splashed whites-but if the two sorts of " wasters" are crossed together blues only will result. 
Selection will never make the blues breed true; nor can this ever come to pass unless a blue be found the germ-cells of which are bearers of the blue character-which may or may not be possible. If the selectionist reflect on this experience he will be led straight to the centre of our problem. There will fall, as it were, scales from his eyes, and in a flash he will see the true meaning of fixation of type, variability, and mutation, vaporous mysteries no more.

Owing to the unhappy subdivisions of our studies, such phenomena as these-constant companions of the breedercome seldom within the purview of modern science, which, forced for a moment to contemplate them, expresses astonishment and relapses into indolent scepticism. It is in the hope that a little may be done to draw research back into these forgotten paths that I avail myself of this great opportunity of speaking to my colleagues with somewhat wider range of topic than is possible within the limits of a scientific paper. For I am convinced that the investigation of heredity by experimental methods offers the sole chance of progress with the fundamental problems of evolution.

In saying this I mean no disrespect to that study of the physiology of reproduction by histological means, which, largely through the stimulus of Weismann's speculations, has of late made such extraordinary advances. It needs no penetration to see that, by an exact knowledge of the processes of maturation and fertilisation, a vigorous stock is being reared, upon which some day the experience of the breeder will be firmly grafted, to our mutual profit. We, who are engaged in experimental breeding, are watching with keenest interest the researches of Strasburger, Boveri, Wilson, Farmer, and their many fellow-workers and associates in this difficult field, sure that in the near future we shall be operating in common. We know already that the experience of the breeder is in no way opposed to the facts of the histologist; but the point at which we shall unite will be found when it is possible to trace in the maturing germ an indication of some character afterwards recognisable in the resulting organism. Until then, in order to pursue directly the course of heredity and variation, it is evident that we must fall back on those tangible manifestations which are to be studied only by field observation and experimental breeding.

The breeding-pen is to us what the test-tube is to the chemist-an instrument whereby we examine the nature of our organisms and determine empirically what for brevity I may call their genetic properties. As unorganised substances have their definite properties, so have the several species and varieties which form the materials of our experiments. Every attempt to determine these definite properties contributes immediately to the solution of that problem of problems, the physical constitution of a living organism. In those morphological studies which I suppose most of us have in our time pursued, we sought inspiration from the belief that in the examination of present normalities we were tracing the past, the phylogenetic order of our types, the history-as we conceived-of Evolution. In the work which I am now pressing upon your notice we may claim to be dealing not only with the present and the past, but with the future also.

On such an occasion as this it is impossible to present to you in detail the experiments-some exceedingly complex -already made in response to this newer inspiration. I mus speak of results, not of methods. At a later meeting, moreover, there will be opportunities of exhibiting practically to those interested some of the more palpable illustrations It is also impossible to-day to make use of the symbolic demonstrations by which the lines of analysis must be represented. The time cannot be far distant when ordinary Mendelian formulæ will be mere as in praesenti to a biological audience. Nearly five years have passed since this extraordinary re-discovery was made known to the scientific world by the practically simultaneous papers of De Vries, Correns, and Tschermak, not to speak of thirtyfive years of neglect endured before. Yet a phenomenon comparable in significance with any that biological science has revealed remains the intellectual possession of specialists. We still speak sometimes of Mendel's hypothesis or theory, but in truth the terms have no strict application. It is ne theory that water is made up of hydrogen and oxygen, though we cannot watch the atoms unite, and it is no theory that the blue Andalusian fowl I produce was made by the meeting of germ-cells bearing respectively black and a peculiar white. Both are incontrovertible facts deduced from observation. The two facts have this in common also, that their perception gives us a glimpse into that hidden order out of which the seeming disorder of our world is built. If I refer to Mendelian " theory," therefore, in the words with which Bacon introduced his Great Instauration, "I entreat men to believe that it is not an opinion to be held, but a work to be done; and to be well assured that I am labouring to lay the foundation, not of any sect or doctrine, but of human utility and power.'

In the Mendelian method of experiment the one essential is that the posterity of each individual should be traced separately. If individuals from necessity are treated collectively, it must be proved that their composition is identical. In direct contradiction to the methods of current statistics, Mendel saw by sure penetration that masses must be avoided. Obvious as this necessity seems when one is told, no previous observer had thought of it, whereby the discovery was missed. As Mendel immediately proved in the case of peas, and as we have now seen in many other plants and animals, it is often impossible to distinguish by inspection individuals whose genetic properties are totally distinct. Breeding gives the only test.

\section{Segregation.}

Where the proper precautions have been taken, the following phenomena have been proved to occur in a great range of cases, affecting many characters in some thirty plants and animals. The qualities or characters the transmission of which in heredity is examined are found to be distributed among the germ-cells, or gametes, as they are called, according to a definite system. This system is such that these characters are treated by the cell-divisions (from which the gametes result) as existing in pairs, each member of a pair being alternative or allelomorphic to the other in the composition of the germ. Now, as every zygote-that is, any ordinary animal or plant-is formed by the union of two gametes, it may either be made by the union of two gametes bearing similar members of any pair, say two blacks or two whites, in which case we call it homozygous in respect of that pair, or the gametes from which it originates may be bearers of the dissimilar characters, say a black and a white, when we call the resulting zygote heterozygous in respect of that pair. If the zygote is homozygous, no matter what its parents or their pedigree may have been, it breeds true indefinitely unless some fresh variation occurs.

If, however, the zygote be heterozygous, or gametically cross-bred, its gametes in their formation separate the allelomorphs again, so that each gamete contains only one allelomorphic character of each pair. At least one celldivision in the process of gametogenesis is therefore a differentiating or segregating division, out of which each gamete comes sensibly pure in respect of the allelomorph it carries, exactly as if it had not been formed by a heterozygous body at all. That, translated into modern language, is the essential discovery that Mendel made. It has now been repeated and verified for numerous characters of numerous species, and, in face of heroic efforts to shake the evidence or to explain it away, the discovery of gametic segregation is, and will remain, one of the lasting triumphs of the human mind.

In extending our acquaintance of these phenomena of segregation we encounter several principal types of complication.

Segregation Absent or Incomplete.-From our general knowledge of breeding we feel fairly well satisfied that true absence of segregation is the rule in certain cases. It is difficult, for instance, to imagine any other account of the facts respecting the American Mulattos, though even here sporadic occurrence of segregation seems to be authenticated. Very few instances of genuine absence of segregation have been critically studied. The only one I can cite from $\mathrm{my}$ own experience is that of Pararge egeria and egeriades, " climatic" races of a butterfly. When crossed together, they give the common intermediate type of North-Western France, which, though artificially formed, breeds in great measure true. This crossed back with either type has given, as a rule, simple blends between intermediate and type. My evidence is not, however, complete enough to 
warrant a positive statement as to the total absence of segregation, for in the few families raised from pairs of artificial intermediates some dubious indications of segregation have been seen.

The rarity of true failure of segregation when pure strains are crossed may be judged by the fact that since the revival of interest in such work hardly any thoroughly satisfactory cases have been witnessed. The largest body of evidence on this subject is that provided by De Vries. These cases, however, present so many complexities that it is impossible to deal with them now. While so little is definitely known regarding non-segregating characters, it appears to me premature to attempt any generalisation as to what does or does not segregate.

Most of the cases of failure of segregation formerly alleged are evidently spurious, depending on the appearance of homozygotes in the second generation $\left(\mathrm{F}_{2}\right)$.

One very important group of cases exists, in which the appearance of a partial failure of segregation after the second generation $\left(\mathrm{F}_{2}\right)$ is really due to another phenomenon. The visible character of a zygote may, for instance, depend on the coexistence in it of two characters belonging to distinct allelomorphic pairs, each capable of being independently segregated from its fellow, and forming independent combinations. For the demonstration of this important fact we are especially indebted to Cuénot. ${ }^{1}$ We have indications of the existence of such a phenomenon in a considerable range of instances (mice, rabbits (Hurst), probably stocks and sweet peas).

Nevertheless, there are other cases, not always easy to distinguish from these, where some of the gametes of $F_{1}$ certainly carry on heterozygous characters unsegregated. As an example, which seems to me indisputable, I may mention the so-called "walnut" comb, normal to Malay fowls. This can be made artificially by crossing rose-comb with pea-comb, and the cross-bred then forms gametes, of which one in four bears the compound unsegregated. ${ }^{2}$ We may speak of this as a true synthesis.

In another type of cases segregation occurs, but is not sharp. The gametes may then represent a full series ranging from the one pure form to the other. Such cases occur in regard to some colours of Primula sinensis, and the leg-feathering of fowls (Hurst). In the second generation a nearly complete series of intermediate zygotes may result, though the two pure extremes (if the case be one of blending characters) may still be found to be pure.

Resolution and Disintegration.-Besides these cases, the features of which we now in great measure comprehend, we encounter frequently a more complex segregation, imperfectly understood, by which gametes of new types, sometimes very numerous, are produced by the crossbred. Each of these new types has its own peculiarities. We shall, I think, be compelled to regard these phenomena as produced either by a resolution of compound characters introduced by one or both parents, or by some process of disintegration, effected by a breaking-up of the integral characters followed by recombinations. It seems impossible to imagine simple recombinations of pre-existing characters as adequate to produce many of these phenomena. Such a view would involve the supposition that the number of characters pre-existing as units was practically infinite-a difficulty that as yet we are not obliged to face. However that may be, we have the fact that resolutions and disintegrations of this kind-or recombinations, if that conception be preferred-are among the common phenomena following crossing, and are the sources of most of the breeder's novelties. As bearing or the theoretical question to which I have alluded, we may notice that it is among

1 When $a b c \ldots \times a \beta \gamma$. gives in $F_{1}$ or $F_{2}$ a character (not seen in the original parents), which from $F_{2}$ or later may breed true : not because $a a, b \beta, c \gamma$ do not severally segregate, but through simultaneous homozygosis of, say, $\alpha a$ and $\beta \beta$, giving a zygote $a \alpha \beta \beta c \gamma .$. which will breed rue to the character $\alpha \beta$.

2 Owing to this behaviour, and to the simultaneous production of singlecomb (? by resolution), there are, even in pure Malays, five types of individuals, all with "walnut" combs-as yet indistinguishable-formed by gametic unions $r \times p, r p \times r p, r p \times r, r p \times p, r p \times s$. Of these kinds three can at once be distinguished by crossing with single; but whether $r \times p$ can be distinguished from $r p \times s$ we do not yet know. [ $r$, rose; $p$, pea; $s$, single; $r p$ walnut.] In this example four allelomorphs are simultaneously segregated, one being compound. Neglecting sexual differentiation, there are therefore ten gametically distinct types theoretically possible; but of these only four are distinguishable by inspection.

$$
\text { No. } 1817 \text {, vOL. } 70]
$$

examples of this complex breaking-up that a great proportion of the cases of partial sterility have been seen.

No quite satisfactory proof as to the actual moment of segregation yet exists, nor have we any evidence that all characters are segregated at the same cell-division. Correns has shown that in maize the segregation of the starch character from the sugar character must happen before the division forming the two generative nuclei, for both bear the same character. The reduction division has naturally been suggested as the critical moment. The most serious difficulty in accepting this view, as it seems to me, is the fact that somatic divisions appear sometimes to segregate allelomorphs, as in the case of Datura fruits, and some colour-cases.

In concluding this brief notice of the complexities of segregation I may direct attention to the fact that we are here engaged in no idle speculation. For it is now possible by experimental means to distinguish almost always with which phenomenon we are dealing, and each kind of complication may be separately dealt with by a determination of the properties of the extracted forms. Illustrations of a. practical kind will be placed before you at a subsequent meeting.

The consequence of segregation is that in cases where it occurs we are rid of the interminable difficulties which beset all previous attempts to unravel heredity. On the older view, the individuals of any group were supposed to belong to an indefinite number of classes, according to the various numerical proportions in which various types had entered into their pedigree. We now recognise that when segregation is allelomorphic, as it constantly is, the individuals are of three classes only in respect of each allelomorphic pair--two homozygous and one heterozygous. In all such cases, therefore, fixity of type, instead of increasing gradually generation by generation, comes suddenly, and is a phenomenon of individuals. Only by the separate analysis of individuals can this fact be proved. The supposition that progress towards fixity of type was gradual arose from the study of masses of individuals, and the gradual purification witnessed was due in the main to the gradual elimination of impure individuals, whose individual properties were wrongly regarded as distributed throughout the mass.

We have at last the means of demonstrating the presence of integral characters. In affirming the integrity of segregable characters we do not declare that the size of the integer is fixed eternally, as we suppose the size of a chemical unit to be. The integrity of our characters depends on the fact that they can be habitually treated as units by gametogenesis. But even where such unity is manifested in its most definite form, we may, by sufficient searching, generally find a case where the integrity of the character has evidently been impaired in gametogenesis, and where one such individual is found the disintegration can generally be propagated. That the size of the unit may be changed by unknown causes, though a fact of the highest significance in the attempt to determine the physical nature of heredity, does not in the least diminish the value of the recognition of such units, or lessen their part in governing the course of Evolution.

The existence of unit-characters had; indeed, long been scarcely doubtful to those practically familiar with the facts of variation ( $c p$. De Vries, "Intracellulare Pangenesis," I889), but it is to the genius of Mendel that we owe the proof. We knew that characters could behave as units, but we did not know that this unity was a phenomenon of gametogenesis. He has revealed to us the underworld of gametes. Henceforth, whenever we see a preparation of germ-cells we shall remember that, though all may look alike, they may in reality be of many and definite kinds, differentiated from each other according to regular systems.

Numerical Relations of Gametes and their Significance.

In addition to the fact of segregation, Mendel's experiments proved another fact nearly as significant; namely, that when characters are allelomorphic, the gametes bearing each member of a pair generally are formed in equal numbers by the heterozygote, if an average of cases be taken. This fact can only be regarded as a consequence of some numerical symmetry in the cell-divisions of gametogenesis. We already know cases where individual families 
show such departure from normal expectation that either the numbers produced must have been unequal, or subsequent disturbance must have occurred. But so far no case is known for certain where the average of families does not point to equality.

The fact that equality is so usual has a direct bearing on conceptions of the physical nature of heredity. I have compared our segregation with chemical separation, but the phenomenon of numerically symmetrical disjunction as a feature of so many and such different characters seems scarcely favourable to any close analogy with chemical processes. If each special character owed its appearance to the handing on of some complex molecule as a part of one chemical system, we should expect, among such a diversity of characters and forms of life, to encounter some phenomenon of valency, manifested as numerical inequality between members of allelomorphic pairs. So far, equivalence is certainly the rule, and where the characters are simply paired and no resolution has taken place, this rule appears to be universal as regards averages. On the other hand, there are features in the distribution of characters after resolution, when the second generation $\left(\mathrm{F}_{2}\right)$ is polymorphic in a high degree, which are not readily accounted for $\mathrm{nn}$ any hypothesis of simple equivalence; but none of these cases are as yet satisfactorily investigated.

It is doubtful whether segregation is rightly represented as the separation of two characters, and whether we may not more simply imagine that the distinction between the allelomorphic gametes is one of presence or absence of some distinguishing element. De Vries has devoted much attention to this question in its bearings on his theory of Pangenesis, holding that cases of both kinds occur, and attempting to distinguish them. Indications may certainly be enumerated pointing in either direction, but for the present I incline to defer a definite opinion.

If we may profitably seek in the physical world for some parallel to our gametic segregations, we shall, I think, find it more close in mechanical separations, such as those which may be effected between fluids which do not freely mix, than in any strictly chemical phenomenon. In this way we might roughly imitate both the ordinary segregation, which is sensibly perfect, and the curious impurity occasionally perceptible even in the most pronounced discontinuities, such as those which divide male from female, petal from sepal, albino from coloured, horn from hair, and so on.

\section{Gametic Unions and their Consequences.}

Characters being then distributable among gametes according to regular systems, the next question concerns the properties and features presented by the zygotes formed by the union of gametes bearing different characters.

As to this no rule can as yet be formulated. Such a heterozygote may exhibit one of the allelomorphic characters in its full intensity (even exceeding it in special cases, perhaps in connection with increased vigour), or it may be intermediate between the two, or it may present some character not recognisable in either parent. In the latter case it is often, though not always, reversionary. When one character appears in such intensity as to conceal or exclude the other it is called dominant, the other being recessive. It may be remarked that frequently, but certainly not universally (as has been stated), the phylogenetically older character is dominant. A curious instance to the contrary is that of the peculiar arrangement of colours seen in a breed of game fowls called Brown-breasted, which in combination with the purple face, though certainly a modern variation, dominates (most markedly in females) over the Black-breasted type of Gallus bankiva.

In a few cases irregularity of dominance has been observed as an exception. The clearest illustration I can offer is that of the extra toe in fowls. Generally this is a dominant character, but sometimes, as an exceptional phenomenon, it may be recessive, making subsequent analysis very difficult. The nature of this irregularity is unknown. A remarkable instance is that of the blue colour in maize seeds (Correns; R. H. Lock). Here the dominance of blue is frequently imperfect, or absent, and the figures suggest that some regularity in the phenomenon may be discovered.

Mendel is often represented as having enunciated dominance as a general proposition. That this statement should still be repeated, even by those who realise the importance of his discoveries, is an extraordinary illustration of the oblivion that has overwhelmed the work of the experimental breeders. Mendel makes the specific statement in regard to certain characters in peas which do behave thus, but his proposition is not general. To convict him of such a delusion it would be necessary to prove that he was exceptionally ignorant of breeding, though on the face of the evidence he seems sufficiently expert.

A generalisation respecting the consequences of heterozygosis possessing, greater value is this. When a pair of gametes unites in fertilisation the characters of the zygote depend directly on the constitution of these gametes, and not on that of the parents from which they came. To this gentralisation we know as yet only two clear exceptions. These vuly curious cases are exactly alike in that, though segregation cbviously occurs in a seed-character, the seeds borne by the hybrid $\left(F_{1}\right)$ all exhibit the hybrid character, and the consequences of segregation in the particular seedcharacter are not evident until the seeds $\left(\mathrm{F}_{3}\right)$ of the second $\left(\mathrm{F}_{2}\right)$ generation are determinable. Of these the first is the case of indent peas investigated especially by Tschermak. Crossed with wrinkled peas I have found the phenomena normal, but when the cross is made with a round type the exceptional phenomenon occurs. The second case is that discovered by Biffen in the cross between the long-grained wheat called Polish and short-grained Rivett wheat, demonstrations of which will be laid before you. No satisfactory account of these peculiarities has been yet suggested, but it is evident that in some unexplained way the maternal plant-characters control the seed-characters for each generation. It is, of course, likely that other comparable cases will be found.

Appearances have been seen in at least four cases (rats, mice, stocks, sweet peas) suggesting at first sight that a heterozygosis between two gametes, both extracted, may give, e.g., dominance; while if one, or both, were pure, they would give a reversionary heterozygote. If this occurrence is authenticated on a sufficient scale, we shall of course recognise that the fact proves the presence in these cases of some pervading and non-segregating quality, distributed among the extracted gametes formed by the parent heterozygote. As yet, however, I do not think the evidence enough to warrant the conclusion that such a pervading quality is really present, and I incline to attribute the appearances to redistribution of characters belonging to independent pairs in the manner elucidated by Cuénot. The point will be easily determined, and meanwhile we must note the two possibilities.

Following, therefore, our first proposition, that the gametes belong to definite classes, comes the second proposition, that the unions of members of the various classes have specific consequences. Nor is this proposition simply the truistical statement that different causes have different effects; for by its aid we are led at once to the place where the different cause is to be sought-Gametogenesis. While formerly we hoped to determine the offspring by examining the ancestry of the parents, we now proceed by investigating the gametic composition of the parents. Individuals may have identical ancestry (and sometimes, to all appearances, identical characters), but yet be quite different in gametic composition; and, conversely, individuals may be identical in gametic composition and have very different ancestry. Nevertheless, those that are identical in gametic composition are the same, whatever their ancestry. Therefore, where such cases are concerned, in any considerations of the physiology of heredity, ancestry is misleading and passes out of account. To take the crudest illustration, if a hybrid is made between two races, $A, B$, and another hybrid between two other races, C, D, it might be thought that when the two hybrids $A B$ and $C D$ are bred together, four races, $A, B, C$, and $D$, will be united in their offspring. This expectation may be entirely falsified, for the celldivisions of gametogenesis may have split A from B and $C$ from $D$, so that the final product may contain characters of only two races after all, being either $\mathrm{AC}, \mathrm{BC}, \mathrm{AD}$, or $\mathrm{BD}$. In practice, however, we are generally dealing with groups of characters, and the union of all the A group, for instance, with all the $\mathrm{C}$ group will be a rare coincidence.

It is the object of Mendelian analysis to state each case of heredity in terms of gametic composition, and thence to 
determine the laws governing the distribution of characters in the cell-divisions of gametogenesis.

There are, of course, many cases which still baffle our attempts at such analysis, but some of the most paradoxical exceptions have been reduced to order by the accumulation of facts. The consequences of heterozygosis are curiously specific, and each needs separate investigation. A remarkable case occurred in stocks, showing the need for caution in dealing with contradictory results. Hoary leaves and glabrous leaves are a pair of allelomorphic characters. When glabrous races were crossed with crossbreds, sometimes the results agreed with simple expectation, while in other cases the offspring were all hoary when, in accordance with similar expectation, this should be impossible. By further experiment, however, Miss Saunders has found that certain glabrous races crossed together give nothing but hoary heterozygotes, which completely elucidates such exceptions. There is every likelihood that wherever segregation occurs similar analysis will be successful.

Speaking generally, in every case the first point to be worked out is the magnitude of the character-units recognised by the critical cell-divisions of gametogenesis, and the second is the specific consequence of all the possible combinations between them. When this has been done for a comprehensive series of types and characters, it will be time to attempt further generalisation, and perhaps to look for light on that fundamental physiological property, the power of cell-division.

Segregation and Sex.-Acquaintance with Mendelian phenomena irresistibly suggests the question whether in all cases of families composed of distinct types the distinctness may not be primarily due to gametic segregation. Of all such distinctions none is so universal. or so widespread as that of sex : may it not be possible that sex is due to a segregation occurring between gametes, either male, female, or both? It will be known to you that several naturalists have been led by various roads to incline to this view. We still await the proof of crucial experiments; but without taking you over more familiar ground, it may be useful to show how the matter looks from our standpoint. As regards actual experiment, all results thus far are complicated by the occurrence of some sterility in the hybrid generation. Correns, fertilising $Q$ Bryonia dioica with pollen from $\Varangle \quad B$. alba, obtained offspring $\left(\mathrm{F}_{1}\right)$ either $\delta$ or $Q$, with only one doubtful exception. Gärtner found a similar result in Lychnis diurna $O \times \varnothing \quad L$. Flos-cuculi

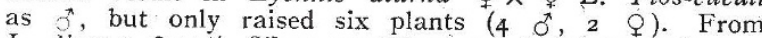
$L$. diurna $q \times \checkmark$ Silene noctiflora as $\delta$ he got only two plants, spoken of as females which developed occasional anthers. These results give a distinct suggestion that sex may be determined by differentiation among the male gametes, but satisfactory and direct proofs can only be obtained from some case where sterility does not ensue.

Apart, however, from such decisive evidence-which, indeed; would be more satisfactory if relating to animals -several circumstances suggest that sex is a segregationphenomenon. Prof. Castle in a valuable essay has directed attention to distinct evidence of disturbance in the heredity of certain moths (Aglia tau and lugens, Standfuss's experiments; Tephrosia, experiments of Bacot and others, summarised by Tutt). ${ }^{2}$ where the disturbance is pretty certainly connected with sexual differentiation. Mr. Punnett and I are finding suggestions of the same thing in certain poultry cases. Mr. Doncaster has pointed out that the evidence of $\mathrm{Mr}$. Raynor clearly indicates that a certain variety of Abraxas grossulariata, usually peculiar to the female, is a Mendelian recessive. It is scarcely doubtful that this will be shown to hold also for some other female varieties, e.g. Colias edusa, var. helice, \&c. We can therefore feel no doubt that there is some entanglement between sex and gametically segregable characters. A curious instance of a comparable nature is that of the Cinnamon canary (Norduijn, \&c.), and similar complications are alleged as regards the descent of colour-blindness and hæmophilia.

In one remarkable group of facts we come very near to the phenomenon of sex. Experiments made in conjunction with Mr. R. P. Gregory have shown that the familiar heterostylism of Primula is a phenomenon of Mendelian segregation. Short style, or "thrum," is a dominant-

1 Trans. Ent. Soc. Lond., 1898. with a complication, " long style, or " pin," is recessive; while -qual, or " homostyle," is recessive to both.

Even nearer we come in a certain sweet-pea example, where abortion of anthers behaves as an ordinary Mendelian recessive character. ${ }^{2}$ By a slight exaggeration we might even speak of a hermaphrodite with barren anthers as a "female."

Consider also how like the two kinds of differentiation are. The occasional mosaicism in Lepidoptera, called " gynandromorphism," may be exactly paralleled by specimens where the two halves are two colour-varieties, instead of the two sexes. Patches of Silene inflata in this neighbourhood commonly consist of hairy and glabrous in dividuals, ${ }^{3}$ a phenomenon proved in Lychnis to be dependent on Mendelian segregation. The same patch consist also of female plants and hermaphrodite plants. Is it not likely that both phenomena are similar in nature? How otherwise would the differentiation be maintained? The sweet-pea case I have spoken of is scarcely distinguishable trom this. I therefore look forward with confidence to the elucidation of the real nature of sex-that redoubtable mystery.

We now move among the facts with an altogether different bearing. "Animals and Plants under Domestication," from being largely a narration of inscrutable prodigies, begins to take shape as a body of coherent evidence. Of the old difficulties many disappear finally. Others are inverted. Darwin says he would have expected " from the law of reversion" that nectarines being the newer form would more often produce peaches than peaches nectarines, which is the commoner occurrence. Now, on the contrary, the unique instance of the Carclew nectarine tree bearing peaches is more astonishing than all the other evidence together!

Though the progress which Mendelian facts make possible is so great, it must never be forgotten that as regards net characters involving the addition of some new factor to the pre-existing stock we are almost where we were. When they have been added by mutation, we can now study their transmission; but we know not whence or why they come. Nor have we any definite light on the problem of adaptation though here there is at least no increase of difficulties.

Besides these outstanding problems, there remain many special points of difficulty which on this occasion I cannot treat-curiosities of segregation, obscure aberrations of fertilisation ${ }^{4}$ (occasionally met with), coupling of characters, and the very serious possibility of disturbance through gametic selection. Let us employ the space that remains in returning to the problem of variation, already spoken of above, and considering how it looks in the light of the new facts as to heredity. The problem of heredity is the problem of the manner of distribution of characters among germcells. So soon as this problem is truly formulated, the nature of variation at once appears. For the first time in the history of evolutionary thought, Mendel's discovery enables us to form some picture of the process which results in genetic variation. It is simply the segregation of a new kind of gamete, bearing one or more characters distinct from those of the type. We can answer one of the oldest questions in philosophy. In terms of the ancient riddle, we may reply that the Owl's egg existed before the Owl; and if we hesitate about the $\mathrm{Owl}$, we may be sure about the Bantam. The parent zygote, the offspring of which display variation, is giving off new gametes, and in its gametogenesis a segregation of their new character, more or less I It is doubtful if "thrum" ever breeds true, as both the other types can do. Perhaps "thrum" is a Halbrasse of De Vries.

2 Neglecting minor complications, the descent is as follows:-Lady Penzance $q \times$ Emily Henderson (long pollen) $\delta$ gave purple $F_{1}$. In one $\mathrm{F}_{2}$ family, with rare exceptions, coloured plants with dark axils were fertile, those with light axils having of sterile, whites being eit her fertile or sterile. The ratios indicated are 9 coloured, $\mathrm{dk}$. ax., fertile $\delta: 3$ coloured, 1t. ax., sterile $\delta: \leqslant$ white, fertile $\delta^{t}: 1$ white, sterile $\delta$. The fertile whites, therefore, though |light-axilled (as whites almost always are) presumably bear the dark-axil character, which generally cannot appear except in association with coloured flowers. This can be proved next year. Some at least of the plants with sterile $\delta$ are fertile on the $q$ side, and when crossed with a coloured light-axilled type will presuniably give only light-axilled plants.

3 This excellent illustration was shown me by Mr. A. W. Hill and Mr. A. Wallis. A third form, glabrous, with hairy edges to the leaves, also occurs.

4 In view of Ostenfeld's discovery of parthenogenesis in Hieracium, the possibility that this phenomenon plays a part in some non-segregating cases needs careful examination. 
pure, is taking place. The significance and origin of the discontinuity of variation is therefore in great measure evident. So far as pre-existing elements are concerned, it is an expression of the power of cell-division to distribute character-units among gametes. The initial purity of so many nascent mutations is thus no longer surprising, and, indeed, that such initial purity has not been more generally observed we may safely ascribe to imperfections of method.

It is evident that the resemblance between the parent originating a variety and a heterozygote is close, and the cases need the utmost care in discrimination. If for instance, we knew nothing more of the Andalusian fowl than that it throws blacks, blues, and whites, how should we decide whether the case was one of heterozygosis or of nascent mutation? The second $\left(\mathrm{F}_{2}\right)$ generation from Brown Leghorn $\times$ White Leghorn contains an occasional SilverGrey or Duckwing female. Is this a mutation induced by crossing, or is it simply due to a recombination of preexisting characters? We cannot yet point to a criterion which will certainly separate the one from the other; but perhaps the statistical irregularity usually accompanying mutation, contrasted with the numerical symmetry of the gametes after normal heterozygosis, may give indications in simple cases-though scarcely trustworthy even there. These difficuities reach their maximum in the case of types which are continually giving off a second form with greater or less frequency as a concomitant of their ordinary existence. This extraordinarily interesting phenomenon, pointed out first by De Vries, and described by him under the head of "Halb-" and "Mittel-Rassen," is too imperfectly understood for me to do more than refer to it, but in the attempt to discover what is actually taking place in variation it must play a considerable part.

Just as that normal truth to type, which we call heredity, is in its simplest elements only an expression of that qualitative symmetry characteristic of all non-differentiating cell-divisions, so is genetic variation the expression of a qualitative asymmetry beginning in gametogenesis. Variation is a novel cell-division. ${ }^{1}$ So soon as this fact is grasped we shall hear no more of heredity and variation as opposing "factors" or "forces"-a metaphor which has too long plagued us

We cease, then, to wonder at the suddenness with which striking variations arise. Those familiar with the older literature relating to domesticated animals and plants will recall abundant instances of the great varieties appearing early in the history of a race, while the finer shades. had long to be waited for. In the sweet pea the old purple, the red bicolor, and the white have existed for generations, appearing soon after the cultivation of the species; but the finer splitting which gave us the blues, pinks, \&c., is a much rarer event, and for the most part only came when crossing was systematically undertaken. If any of these had been seen before by horticulturists, we can feel no doubt whatever they would have been saved. An observer contemplating a full collection of modern sweet peas, and ignorant of their history, might suppose that the extreme types had resulted from selective and more or less continuous intensification of these intermediates, exactly inverting the truth.

We shall recognise among the character-groups lines of cleavage, along which they easily divide, and other finer subdivisions harder to effect. Rightly considered, the sudden appearance of a total albino or a bicolor should surprise us less than the fact that the finer shades can appear at all.

At this point comes the inevitable question, what makes the character-group split? Crossing, we know, may do this; but if there be no crossing, what is the cause of variation? With this question we come sharply on the edge of human knowledge. But certain it is that if causes of variation are to be found by penetration, they must be specific causes. A mad dog is not " caused" by July heat, nor a moss rose by progressive culture. We await our Pasteur; founding our hope of progress on the aphorism of Virchow, that every variation from type is due to a pathological accident, the true corollary of "Omnis cellula $e$ cellula."

I The parallel between the differentiating divisions by which the parts of the normal body are segregated from each other, and the segregating processes of gametogenesis, must be very close. Occasionally we even see the segregation of Mendelian characters among zygotic cells.
In imperfect fashion I have now sketched the lines by which the investigation of heredity is proceeding, and some of the definite results achieved. We are asked sometimes, Is this new knowledge of any use? That is a question with which we, here, have fortunately no direct concern. Our business in life is to find things out, and we do not look beyond. But as regards heredity, the answer to this question of use is so plain that we may give it without turning from the way.

We may truly say, for example, that even our present knowledge of heredity, limited as it is, will be found of extraordinary use. Though only a beginning has been made, the powers of the breeder of plants and animals are vastly increased. Breeding is the greatest industry to which science has never yet been applied. This strange anomaly is over; and, so far at least as fixation or purification of types is concerned, the breeder of plants and animals may henceforth guide his operations with a great measure of certainty.

There are others who look to the science of heredity with a loftier aspiration; who ask, Can any of this be used to help those who come after to be better than we arehealthier, wiser, or more worthy? The answer depends on the meaning of the question. On the one hand it is certain that a competent breeder, endowed with full powers, by the aid even of our present knowledge, could in a few generations breed out several of the morbid diatheses. As we have got rid of rabies and pleuro-pneumonia so we could exterminate the simpler vices. Voltaire's cry, "Ecraser l'infame!" might well replace Archbishop Parker's Table of Forbidden Degrees, which is all the instruction Parliament has so far provided. Similarly, a race may conceivably be bred true to some physical and intellectual characters considered good. The positive side of the problem is less hopeful, but the various species of mankind offer ample material. In this sense science already suggests the way. No one, however, proposes to take it; and so long as, in our actual laws of breeding, superstition remains the guide of nations, rising ever fresh and unhurt from the assaults of knowledge, there is nothing to hope or to fear from these sciences.

But if, as is usuai, the philanthropist is seeking for some external application by which to ameliorate the course of descent, knowledge of heredity cannot help him. The answer to his question is $\mathrm{No}$, almost without qualification. We have no experience of any means by which transmission may be made to deviate from its course; nor from the moment of fertilisation can teaching, or hygiene, or exhortation pick out the particles of evil in that zygote, or put in one particle of good. From seeds in the same pod may come sweet peas climbing five feet high, while their own brothers lie prone upon the ground. The stick will not make the dwarf peas climb, though without it the tall can never rise. Education, sanitation, and the rest, are but the giving or withholding of opportunity. Though in the matter of heredity every other conclusion has been questioned, I rejoice that in this we are all agreed.

\section{NOTES.}

THE sum of rol. has been granted by the Paris Municipal Council to Prof. Grancher in furtherance of his researches as to the means of preventing tuberculosis in schools.

ON Monday and Tuesday, September I2 and I3, a visit is to be paid to London by a large party of Belgian engineers, members of the Association des ingénieurs sortis de l'Ecole de Liège-one of the most important technical societies on the Continent. The party will be the guests of the Iron and Steel Institute.

Prof. Appell, dean of the faculty of sciences in the University of Paris, has had the civil title of commandeur de la Légion d'honneur conferred upon him by the French Minister of War. Prof. Appell has served for some time on the commission appointed to examine inventions likely to be of service to the French Army and Navy. 